\title{
Geochronological constraints on the carbonate-sulfarsenide veins in Dobšiná, Slovakia: U/Pb ages of hydrothermal carbonates, Re/Os age of gersdorffite, and K/Ar ages of fuchsite
}

\author{
Stefan KIEFER ${ }^{1 *}$, Martin ŠTEVKO ${ }^{2,3}$, Rastislav VOJTKO ${ }^{4}$, Daniel OZDÍN ${ }^{5}$, Axel GERDES ${ }^{6,7}$, \\ Robert A. CREASER ${ }^{8}$, Marek SZCZERBA ${ }^{9}$, Juraj MAJZLAN ${ }^{1}$
}

\author{
${ }^{1}$ Institute of Geosciences, Friedrich-Schiller University, Burgweg 11, D-07749 Jena, Germany; email: stefan.kiefer@uni-jena.de \\ ${ }^{2}$ Earth Science Institute, Slovak Academy of Sciences, Dúbravská cesta 9, 84005 Bratislava, Slovakia \\ ${ }^{3}$ Department of Mineralogy and Petrology, National Museum, Cirkusová 1740, CZ-19300 Praha 9, Czech Republic \\ ${ }^{4}$ Department of Geology and Palaeontology, Comenius University, Ilkovičova 6, SK-842 15 Bratislava, Slovakia \\ ${ }^{5}$ Department of Mineralogy and Petrology, Comenius University, Ilkovičova 6, SK-842 15 Bratislava, Slovakia \\ ${ }^{6}$ Department of Geosciences, Goethe University Frankfurt, Altenhöferallee 1, D-60438 Frankfurt, Germany \\ ${ }^{7}$ Frankfurt Isotope and Element Research Center (FIERCE), Goethe University Frankfurt, Germany \\ ${ }^{8}$ Department of Earth and Atmospheric Sciences, University of Alberta, Edmonton, Alberta T6G 2E3, Canada \\ ${ }^{9}$ Institute of Geological Sciences, Polish Academy of Sciences, ul. Senacka 1, 31-002 Krakow, Poland \\ * Corresponding author
}

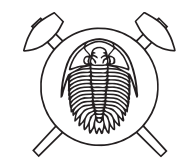

The abandoned deposit Dobšiná in eastern Slovakia used to be exploited for Ni-Fe-Co sulfarsenides in siderite-ankerite hydrothermal veins. These veins are locally accompanied by alteration zones of fuchsite-quartz-carbonate rocks. The $\mathrm{Ni}-\mathrm{Fe}-\mathrm{Co}$ sulfarsenides are postdated by chalcopyrite and tetrahedrite. This work aims to determine the age of these mineralizations utilizing $\mathrm{U} / \mathrm{Pb}, \mathrm{Re} / \mathrm{Os}$, and $\mathrm{K} / \mathrm{Ar}$ dating of selected minerals. $\mathrm{U} / \mathrm{Pb}$ dating of hydrothermal siderite and ankerite gave ages from $145 \pm 5 \mathrm{Ma}$ to $114 \pm 24 \mathrm{Ma}$. They broadly coincide with the metamorphic peak in the Gemeric Unit and the formation of the Gemeric cleavage fan (CGF) during partial exhumation of this unit. Hydrothermal gersdorffite was dated (Re/Os) to $93.6 \pm 0.9 \mathrm{Ma}$, the time of exhumation of the Gemeric unit. No data were extracted for the younger $\mathrm{Cu}$ sulfides. By correlation with other units in the Western Carpathians, they could be assigned Late Cretaceous age, corresponding to welding of the Gemeric and Veporic units and the formation of the Trans-Gemeric shear zone. The fuchsite rocks were dated (K/Ar) to $110 \mathrm{Ma}$, but this datum conflicts with textural evidence, which shows that these rocks are older than the hydrothermal carbonates. The age of $110 \mathrm{Ma}$ is therefore considered to be cooling age after the reset of the geochronometer by the Alpine metamorphism, in agreement with earlier data. The geochronological results are supported by structural measurements and field observations. The main mineralized zone, investigated in one of the accessible adits, conforms with the Variscan - ?Alpine metamorphic foliation. There are also younger, less significant structures whose relevance to the ore mineralization is not yet clear.

Keywords: hydrothermal mineralization, geochronology, ore mineralogy, isotopic dating Received: 14 May 2020; accepted: 21 October 2020; handling editor: P. Jeřábek

\section{Introduction}

The ore mineralizations around the small township Dobšiná in eastern Slovakia include many hydrothermal veins that contain siderite, quartz, arsenides, and sulfides of $\mathrm{Ni}, \mathrm{Co}, \mathrm{Cu}, \mathrm{Sb}$ (Halahyjová-Andrusovová 1961, 1964; Grecula et al. 1995; Mesarčík et al. 2001; Kiefer et al. 2017). Additionally, metasomatic bodies of siderite/ ankerite were mined here in the past. The $\mathrm{Ni}-\mathrm{Fe}-\mathrm{Co}$ mineralization in Dobšiná is hosted by the Gemeric Unit, one of the major thick-skinned tectonic units of the Central Western Carpathians (Fig. 1). Beside the ores in Dobšiná, the Gemeric Unit hosts more than 1200 ore bodies (Fig. 1; Grecula et al. 1995) that can be roughly divided into siderite-quartz-sulphide and quartz-stibnite assemblages. Many of the ore bodies were of significant economic importance in the past.

An excellent summary of the development of the ideas and perception of the hydrothermal $\mathrm{Ni}-\mathrm{Fe}-\mathrm{Co}$ mineralization in Dobšiná was written in the Slovak language by Mesarčík et al. (2001) and a digest thereof will be given here. The early studies of Böckh (1908) and Woldřich (1912) link the hydrothermal mineralization to the gneissamphibolite complex, granites, or both. Woldřich (1912, 1927) anticipated Early Carboniferous age of the veins because he assumed that the post-mineralization tectonics was of Upper Carboniferous age. Ahlburg (1913) found limonite-rich pebbles in Carboniferous conglomerates, assumed that these conglomerates represent weathered siderite ores and postulated their pre-Carboniferous age. 


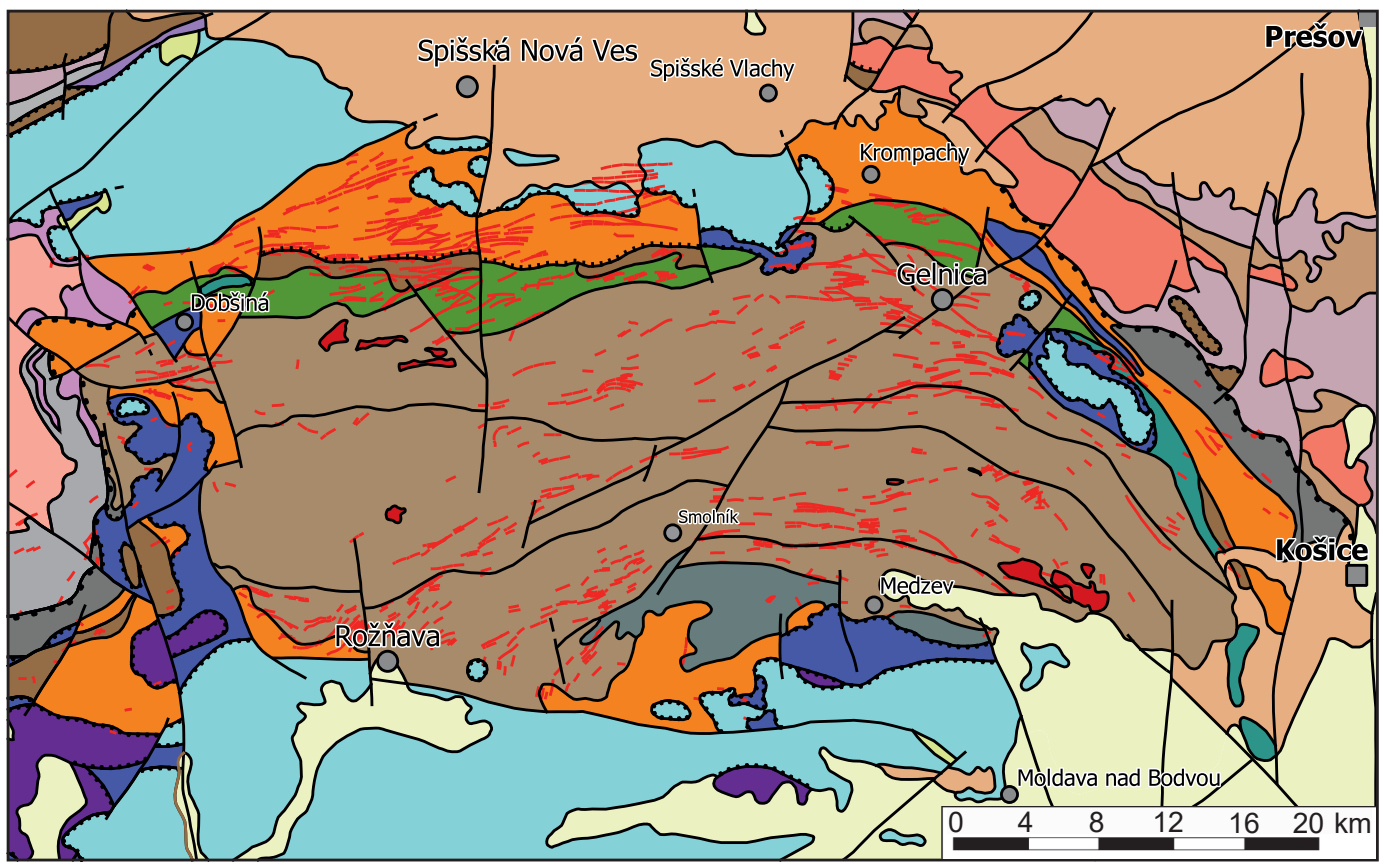

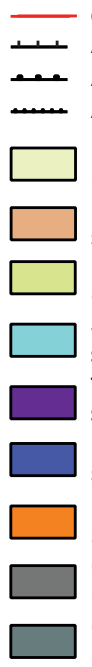

ore vein

Alpine reverse faults

Alpine thick-skinned thrust

Alpine superficial thrust

Neogene and Quaternary

sedimentary deposits

Eocene-Oligocene

sedimentary deposits

Upper Cretaceous-Paleocene

sedimentary deposits

Silicic Unit (Upper Permian-Middle Jurassic

sedimentary deposits

Turnaic Unit (Upper Carboniferous-Upper Triassic

sedimentary deposits

Meliatic Unit s.s. and Bôrka Unit (Permian-Jurassic)

sedimentary deposits, ophiolites

Gemeric Unit Permian to Triassic

sedimentary deposits with acidic volcanites

Gemeric Unit - Ochtiná and Črmel' nappes

(Carboniferous sedimentary deposits with magnezites)

Gemeric Unit - Štós nappe

(Lower Devonian metasandstone ans phyllite)

Fig. 1 Geological map of the Gemeric unit and adjoining areas.

Papp (1919) linked the ores to the quartz porphyries and presumed their Permian age. The first views that there may be two separate stages of mineralization can be attributed to Ulrich (1928). The older stage could be connected to the basic rocks of the gneiss-amphibolite complex; the younger one is a result of remobilization. Other authors seek the source of the mineralization in the granitic rocks (Kettner 1921; Hynie 1922), but their ideas about the age of these granites diverge. Zoubek (1937), in contrast to all these studies, identified the Alpine metamorphism as the source of the mineralization. Hence, the dichotomy of the Variscan versus Alpine age of the veins dates back to the early years, although many details of geology and geochronology of the host rocks were unknown at that time.
Gemeric Unit - Rakovec Group (back-arc basin, Middle-Upper gabbrodiorite, metabasalt, metasandstone, and phyllite)

Gemeric Unit - Klátov Group (oceanic crust, Devonian?)

Gemeric Unit - Gelnica Group (Upper Cambrian-Devonian metasediments with acid-intermediate volcanics)

Gemeric Unit - two-mica granite mostly Permian

Hronic Unit - mostly Triassic shelf limestone

Hronic Unit - Upper Paleozoic sedimentary deposits with tholeiitic basalt

Southern Veporic Unit - mostly metamorphosed Triassic sedimentary deposits

Southern Veporic Unit - Upper Carboniferous

metapsamite to metapelite

Southern Veporic Unit - Late Variscan

porpfyric granitoids and orthogneiss

Northern Veporic Unit - Mesozoic

sedimentary formations

Northern Veporic Unit - Upper Paleozoic

sedimentary formations

Northern Veporic Unit - Late Variscan

porpfyric granitoids, orthogneiss, and migmatite
The Alpine age of the veins was proposed and defended by Máška (1957), Varček (1962, 1985), and Bernard (1963). Some of them linked the mineralization to the granites, assuming their Cretaceous age. Rozložník (1989) insisted on the Cretaceous (or even younger) age even though at that time, the Permian age of the granites was already known. On the other hand, Ilavský (1986) maintained that the mineralizations are Variscan, connected to the voluminous granitic magmatic activity in those times.

The dichotomy persisted until today. Currently, there are two competing models that address the origin and timing of the ore mineralizations in the Gemeric Unit. Radvanec et al. (2004) linked the siderite-quartz-sulfide 
ores to Permian regional fluid flow, initiated by the uplift of the Variscan metamorphic core complex. This assignment is based on 'available indirect data' and Radvanec et al. (2004) also stated that 'more geochronological data both on metamorphic rocks and individual mineralization stages are needed to clarify all relationships unambiguously'. On the other hand, Hurai et al. $(2006,2015)$ tied the mineralizations to the deeply buried rocks complexes under the stack of nappes thrust over the Gemeric Unit in Cretaceous times. The deep formation environments were confirmed also by the finds of superdense $\mathrm{CO}_{2}$ (Urban et al. 2006) and $\mathrm{N}_{2}$ inclusions (Hurai et al. 2008), which are incompatible with the regional fluid flow of a rock complex that is being exhumed. The Alpine greenschist facies metamorphic condition is also indicated by zircon fission-track data, which yielded ages of 115-75 Ma. Most probably, these data refer to two stages of the Gemeric Unit evolution during the Alpine orogeny. The older ages can be related to thrusting or final emplacement of the Gemeric Unit onto the Veporic Unit (115-100 $\mathrm{Ma}$ ) and the younger ages are related to final exhumation of the Gemeric Unit during the orogenic collapse (90-75 Ma) (cf. Plašienka et al. 2007; Králiková et al. 2016). The Alpine (mostly Cretaceous) ages were also confirmed by chemical electron-microprobe (CHIME) and laserablation ICP-MS dating of accessory monazite associated with the gangue minerals of the quartz-tourmaline stage. The relevance of its age, however, to the main siderite or sulfide stages may be difficult to establish. Some early $\mathrm{K} / \mathrm{Ar}$ dating of the shear zones, showing their particular Cretaceous thermal and dynamic activity (Mesarčík et al. 2001, p. 68) was indirectly questioned by Radvanec et al. (2004) who concluded that "Alpine metamorphism ... frequently reset Ar isotope systems to Alpine ages".

One way of addressing this problem is the direct dating of major minerals of the ore veins. Even though not every mineral can be easily dated, the rapid advance in multi-collector (MC) mass spectrometers (MS) linked to inductively-coupled plasma (ICP) systems allow dating of matrices, which was unthinkable only a decade ago. Connected with a superior spatial resolution of a laserablation (LA) system, the LA-MC-ICP-MS analyses of the $\mathrm{U} / \mathrm{Pb}$ isotopic system can provide new insights into geological and metallogenetic questions and resolve, at least to some extent, the temporal dichotomy of the Gemeric ore veins. There was significant progress in other isotope systems used in geochronology, for example, the $\mathrm{Re} / \mathrm{Os}$ system. Apart from molybdenite, used commonly for $\mathrm{Re} / \mathrm{Os}$ dating, other minerals, such as arsenopyrite (e.g., Morelli et al. 2005), have been subjected to this type of analysis. This contribution makes use of the substantial progress in geochronological techniques and addresses the question of the age of the Gemeric mineralization systems in a case study in Dobšiná. We are presenting LA-MC-ICP-MS U/Pb dating of hydrothermal siderite and ankerite from Dobšiná, $\mathrm{K} / \mathrm{Ar}$ ages of the $\mathrm{Cr}$ mica (fuchsite) closely associated with the ore veins, and $\mathrm{Re} / \mathrm{Os}$ dating of gersdorffite, a major ore mineral of the hydrothermal veins studied (Halahyjová-Andrusovová 1961, 1964; Kiefer et al. 2017).

\section{Geological evolution of the studied area}

The area around Dobšiná is known for its complicated geological settings located in the internal zones of the Central Western Carpathians (CWC). The CWC forms the core of the Carpathian Orogen, which underwent a complex Variscan and Alpine structural and metamorphic evolution and it contains several nappe units of various orders and ages. In the study area, there are two main types of tectonic units (Fig. 1): (i) thick-skinned thrust sheets, which comprise the pre-Alpine crystalline basement along with its Upper Palaeozoic to Mesozoic sedimentary cover (the Veporic and Gemeric units); and (ii) detached cover nappe systems containing Upper Palaeozoic to Mesozoic sedimentary formations with rare volcanic rocks (the Meliatic, Turnaic, and Silicic units).

The Veporic Unit was overridden by the Gemeric Unit, which consists of amphibolite-facies metamorphic rocks of the Klátov Group (Spišiak et al. 1985), greenschist facies metabasites and phyllites (ophiolitic) of the Rakovec Group, and the greenschist facies volcano-sedimentary sequences of the Gelnica Group. These Gemeric crystalline complexes are covered by Upper Carboniferous to Middle Triassic volcano-sedimentary succession of Variscan molasse, affected by subsequent Alpine anchimetamorphism. Younger formations than the Middle Triassic are unknown in the Gemeric cover sequence. The main phase of crustal shortening and nappe formation took place during the late Early Cretaceous $(\approx 137-115$ Ma) immediately after the closure of the Triassic-Jurassic Meliata Ocean ( $\approx 155-145 \mathrm{Ma})$, followed by the formation of an accretionary complex (Kozur and Mock 1973; Maluski et al. 1993; Faryad and Henjes-Kunst 1997; Árkai et al. 2003; Dallmeyer et al. 2008; Hurai et al. 2008, 2015; Vozárová et al. 2014). This earliest stage of the Cretaceous N-S convergence in $\mathrm{CWC}$ orogenic wedge is recorded in the Gemeric Unit by the formation of Alpine metamorphic foliation mainly in incompetent lithologies partly to disjunctive foliations developed in competent rocks of the unit and probably represent a gradual transition from bedding or Variscan to Alpine structure (cf. Hrouda and Faryad 2017).

Later, the tectono-metamorphic overprint is associated with the evolution of a large-scale cleavage fan structure across the entire unit (Lexa et al. 2003). The evolution of 
Samples and Localities

\section{DBK1 Zemberg-Terézia vein system DN1 Zemberg-Terézia vein system DN2 Zemberg-Terézia vein system DN3 Zemberg-Terézia vein system DN4 Zemberg-Terézia vein system DR1 Martini vein system DR2 Martini vein system DR3 Martini vein system DR4 Martini vein system DE1 Martini vein system}

Metabasite and tuffites

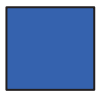

Amphibolite

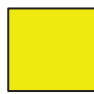

Biotite-amphibolite gneiss

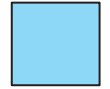

Sandstone and schists

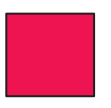

Fuchsite quartzites siderite, ankerite Deposits of the Georgi-type

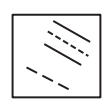

Faults

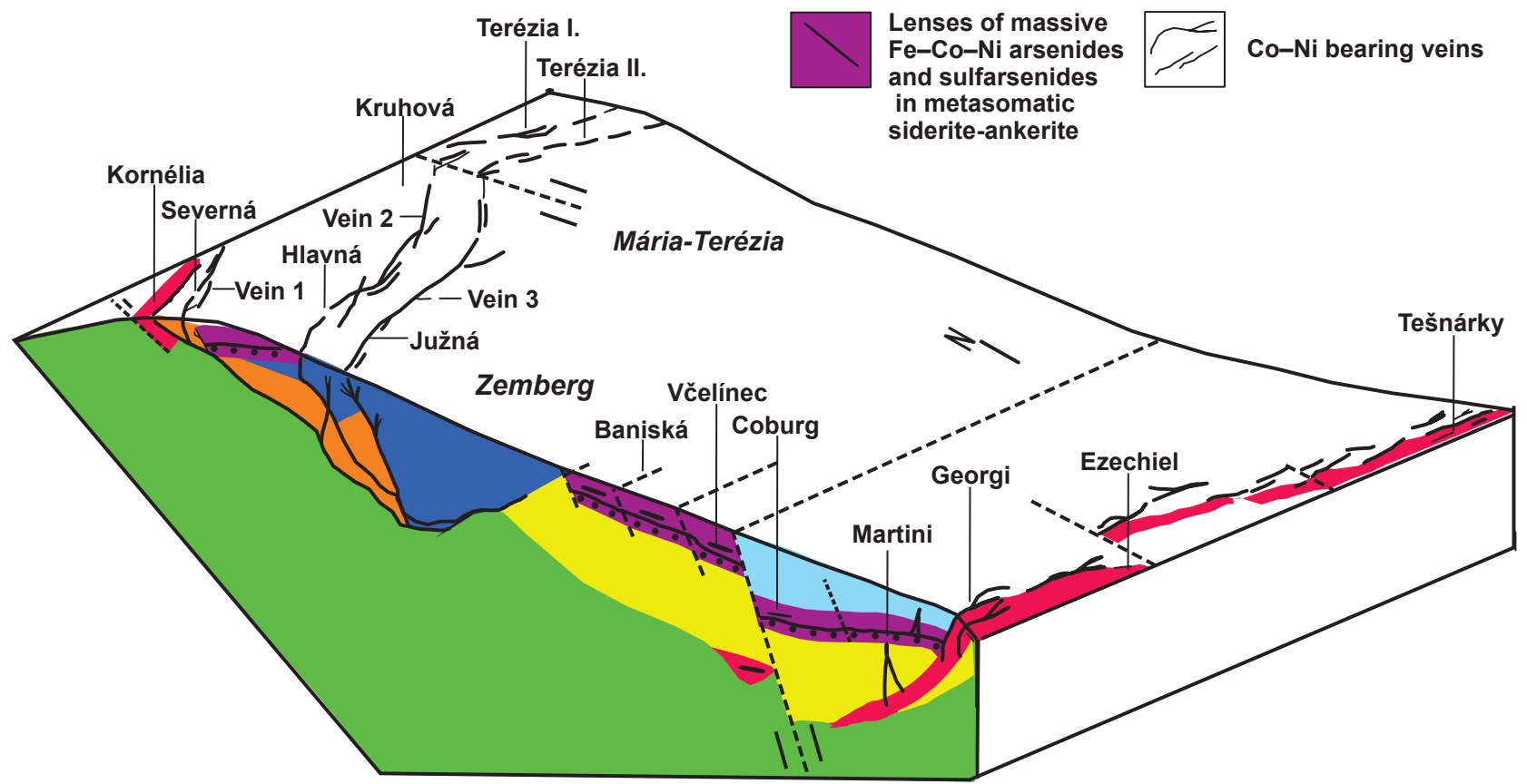

Fig. 2 Geological profile of the southern slopes of Kruhová hill near the town of Dobšiná (profile simplified after Grecula et al. 1995).

the Gemeric cleavage fan is associated with overthrusting of the Gemeric Unit over the underlying Veporic Unit in the north during the late Early Cretaceous (Lexa et al. 2003; Jeřábek et al. 2012; Novotná et al. 2015; Vojtko et al. 2016). The Gemeric Unit is overlain by a subductionrelated melange of sediments and relics of oceanic mantle rocks of the Jurassic Meliata Ocean. The metamorphic conditions of Jurassic accretionary wedge composed of the Meliata, Turňa related rocks correspond to blueschist or greenschist facies for Alpine regional metamorphism (e.g., Faryad 1995, 1997). The Jurassic accretionary wedge and the underlying Gemeric Unit are tectonically overlain by extensive horizontally lying unmetamorphosed Silica nappe system derived most probably from the Apulian shelf (Fig. 1).

The system of siderite-type hydrothermal carbonatequartz veins with $\mathrm{Ni}-\mathrm{Fe}-\mathrm{Co}-\mathrm{Cu}$ ore mineralization near
Dobšiná is hosted in Early Paleozoic gneiss-amphibolite complex of the Klátov group belonging to the Gemeric Unit. Minor occurrences of $\mathrm{Ni}-\mathrm{Fe}-\mathrm{Co}$ ores are known from the metasomatic bodies of siderite hosted in Carboniferous rocks (Fig. 2). The two principal vein systems were distinguished. The Zemberg-Terézia vein system is located at the northern margin of the gneiss-amphibolite complex and the Martini vein system, which is situated at the southern margin of the same complex (Rozložník 1959, 1965; Halahyjová-Andrusovová 1964; Grecula et al. 1995; Mesarčík et al. 2001). The Zemberg-Terézia vein system is subdivided by the $\mathrm{N}-\mathrm{S}$ trending fault to western (Zemberg) and eastern (Terézia) segments. The Zemberg segment generally consists of three (Severná, Hlavná and Južná vein) and Terézia segment of two (Terézia I., Terézia II.) veins. The Martini vein system consists of four major (Jacobi, Ezechiel, Martini, 
Tešnárky) and several minor veins (Grecula et al. 1995; Mesarčík et al. 2001).

\section{Samples and Methods}

Most of the samples used in this study were collected in the old mines with a precise localization (Details are included in Tab. 1). Samples of fresh hydrothermal carbonates (siderite and dolomite-ankerite series) were collected in-situ in the abandoned adits located both at the Zemberg-Terézia vein system (Karol adit-DBK1, Lower Jórémeny adit-DN1 to DN4) and Martini vein system (Remény adit - DR1 to DR4). Fuchsite samples were collected from the Martini vein system (DR3 - underground from the Remény adit and DE-1 from the dump of the Lower Ezechiel adit). Samples rich in the hydrothermal Ni-Co arsenides were collected by Halahyjová-Andrusovová $(1961,1964)$ from both vein systems and recently re-investigated by Kiefer et al. (2017).

All samples have been examined in the form of polished sections with a Zeiss-Axio-Imager.M2m optical microscope equipped with a CCD-camera system. The chemical composition of the hydrothermal carbonates and the ore minerals was determined by electron microprobe analyses using a JEOL JXA-8230 instrument. For the carbonate minerals, the operating conditions were set to an accelerating voltage of $15 \mathrm{kV}$, a beam current of $15 \mathrm{nA}$ and a beam diameter of $1 \mu \mathrm{m}$. The wavelength-dispersive $\mathrm{X}$-ray spectrometers were used to measure the elements and X-ray lines of $\mathrm{Mg}\left(K_{\alpha}\right), \mathrm{Si}\left(K_{\alpha}\right), \operatorname{Sr}\left(L_{\alpha}\right), \mathrm{Ba}\left(M_{\alpha}\right), \mathrm{Ca}$ $\left(K_{\alpha}\right)$, Fe $\left(K_{\alpha}\right)$, and $\mathrm{Mn}\left(K_{\alpha}\right)$. To improve the count-rate statistics, the counting times were $40 \mathrm{~s}$. The standard specimens used for calibration were $\mathrm{MgO}$ for $\mathrm{Mg}$, rhodonite for $\mathrm{Si}$ and $\mathrm{Mn}$, celestine for $\mathrm{Sr}$, baryte for $\mathrm{Ba}$, apatite for $\mathrm{Ca}$, and hematite for $\mathrm{Fe}$. The detection limits, calculated from the peak and background counts, the measurement time and the standard material concentration, are 0.03 wt. \% for Si, 0.02 wt. \% for $\mathrm{Mg}, 0.09$ wt. \% for $\mathrm{Ba}, 0.09$ wt. \% for $\mathrm{Sr}, 0.02$ wt. \% for $\mathrm{Ca}, 0.05$ wt. \% for $\mathrm{Fe}$ and 0.05 wt. $\%$ for Mn. The ore minerals, mainly sulfarsenides, were analyzed with an accelerating voltage of $20 \mathrm{kV}$, a beam current of $50 \mathrm{nA}$, a beam diameter of $1 \mu \mathrm{m}$ and counting times of $40 \mathrm{~s}$. The measured elements and lines were $\mathrm{As}\left(K_{\alpha}\right), \mathrm{S}\left(K_{\alpha}\right), \mathrm{Sb}\left(L_{\alpha}\right), \mathrm{Pb}\left(M_{\alpha}\right), \mathrm{Ni}\left(K_{\alpha}\right)$, $\mathrm{Co}\left(K_{\alpha}\right)$, and $\mathrm{Fe}\left(K_{\alpha}\right)$. The standard specimens used were: arsenopyrite for As, pyrite for S and Fe, pure metal standards for $\mathrm{Ni}$ and $\mathrm{Co}$, galena for $\mathrm{Pb}$ and stibnite for $\mathrm{Sb}$. The detection limits, calculated after the same procedure as the above mentioned, were: 0.04 wt. $\%$ for $\mathrm{Sb}, 0.08$ wt. \% for $\mathrm{Pb}, 0.07$ wt. \% for As, and 0.02 wt. \% for $\mathrm{S}$, $\mathrm{Co}, \mathrm{Cu}, \mathrm{Fe}$, and $\mathrm{Ni}$. The elements analyzed but not listed in the corresponding tables $(\mathrm{Pb}, \mathrm{Cu})$ were always below the detection limit.The rocks at the vast majority of exposures possess particular planar structure. In metamorphic rocks, a planar structure is known as metamorphic or tectonic foliation (cleavage, schistosity). In this paper, we use foliation as a general term for all pervasively developed planar structures found in rocks. The second type of planar structure were veins with their typical tabular shape, which were deformed during the tectonogenesis. Structures in rocks with linear, as opposed to planar, the character also occur in many forms. Observed lineations are both mineral lineations (linear alignments of minerals in metamorphic tectonites) and stretching lineations defined by strained objects with elongated, cigar-like shapes. These lineations were measured on vein surfaces to provide information on the direction of movement during or after the vein formation. All oriented data were processed in the stereographic projection (Lambert net), lower hemisphere using the FaultKin 7.5 (Marrett and Allmendinger 1990; Allmendinger et al. 2013).Uranium- $\mathrm{Pb}$ ages were acquired in situ in thick polished section by laser ablation-sector field-inductively coupled

Tab. 1 Localities and general mineralogy of the samples used in this work

\begin{tabular}{|c|c|c|c|c|}
\hline Sample & Location & Mineral & Associated minerals & Host rock \\
\hline DBK1 & $\begin{array}{l}\text { Zemberg-Terézia vein system, } \\
\text { Karol adit-Južná vein }\end{array}$ & dolomite-ankerite series & quartz, nickeline, gersdorffite & gneiss \\
\hline DN1 & $\begin{array}{l}\text { Zemberg-Terézia vein system, } \\
\text { Lower Jórémeny adit-Severná vein }\end{array}$ & dolomite-ankerite series & quartz, arsenopyrite, gersdorffite & gneiss-amphibolite \\
\hline $\mathrm{DN} 2$ & $\begin{array}{l}\text { Zemberg-Terézia vein system, } \\
\text { Lower Jórémeny adit-Severná vein }\end{array}$ & dolomite-ankerite series & quartz, arsenopyrite, gersdorffite & gneiss-amphibolite \\
\hline DN3 & $\begin{array}{l}\text { Zemberg-Terézia vein system, } \\
\text { Lower Jórémeny adit-Severná vein }\end{array}$ & dolomite-ankerite series & quartz, arsenopyrite, gersdorffite & gneiss-amphibolite \\
\hline DN4 & $\begin{array}{l}\text { Zemberg-Terézia vein system, } \\
\text { Lower Jórémeny adit-Severná vein }\end{array}$ & dolomite-ankerite series & quartz, arsenopyrite, gersdorffite & gneiss-amphibolite \\
\hline DR1 & Martini vein system, Remény adit-Jacobi vein & siderite & gersdorffite & gneiss \\
\hline DR2 & Martini vein system, Remény adit-Jacobi vein & $\begin{array}{l}\text { siderite, dolomite-ankerite } \\
\text { series }\end{array}$ & gersdorffite & gneiss \\
\hline DR3 & Martini vein system, Remény adit-Jacobi vein & fuchsite & quartz, siderite & gneiss \\
\hline DR4 & Martini vein system, Remény adit-Jacobi vein & dolomite-ankerite series & arsenopyrite & gneiss \\
\hline DE1 & Martini vein system, Lower Ezechiel adit-dump & fuchsite & siderite, gersdorffite & gneiss-amphibolite \\
\hline
\end{tabular}


plasma-mass spectrometry (LA-SF-ICPMS) at the Goethe University Frankfurt (GUF). At GUF a ThermoScientific Element 2 sector field ICP-MS is coupled to a RESOLution S-155 (Resonetics) $193 \mathrm{~nm}$ ArF Excimer laser (CompexPro 102, Coherent) equipped with a twovolume ablation cell (Laurin Technic, Australia). Static ablation in a helium atmosphere $(0.3 \mathrm{l} / \mathrm{min})$ used a spot size of $213 \mu \mathrm{m}$ and a fluence of ca. $1 \mathrm{~J} \mathrm{~cm}-2$ at $6 \mathrm{~Hz}$. Soda-lime glass SRM-NIST614 was used as a reference glass together with 3 carbonate standards to bracket sample analysis. Raw data were corrected offline using a macro-based in-house MS Excel $\odot$ spreadsheet program (Gerdes and Zeh 2009). The ${ }^{207} \mathrm{~Pb} /{ }^{206} \mathrm{~Pb}$ ratio was corrected for mass bias $(0.6 \% / \mathrm{amu})$ and the ${ }^{206} \mathrm{~Pb} /{ }^{238} \mathrm{U}$ ratio for inter-element fraction (ca. $5 \%$ ). Due to the carbonate matrix, additional correction of $9 \%$ has been applied on the ${ }^{206} \mathrm{~Pb} /{ }^{238} \mathrm{U}$, which was determined using WC-1 carbonate reference material dated by TIMS $(254 \pm 6 \mathrm{Ma}$; Roberts et al. 2017). All reported uncertainties are the $2 \sigma$ level. For the Re/Os geochronological analyses, acquired at the University of Alberta, ten samples of $\mathrm{Ni}-\mathrm{Fe}-\mathrm{Co}$ arsenides were selected for preliminary analyses, and only three of them contained sufficient Re to be considered further. These three samples were analyzed by the methods described in detail by Selby and Creaser (2004) and Morelli et al. (2010). Initially, the Re abundance in each of 3 mineral separates was tested by isotope dilution analysis and found to be suitable for one sample only (sample 436: $10.0 \mathrm{ppb} \operatorname{Re}, 12 \mathrm{~d}$ : $0.2 \mathrm{ppb} \operatorname{Re}, 25 \mathrm{~b}: 2.0 \mathrm{ppb}$ $\mathrm{Re})$. An initial full Re-Os analysis revealed little common Os was present, with ${ }^{187} \mathrm{Os}^{*}$ comprising $>99.7 \%$ of the Os measured. As such, for this work, a mixed double spike containing known amounts of isotopically enriched ${ }^{185} \mathrm{Re},{ }^{190} \mathrm{Os}$, and ${ }^{188} \mathrm{Os}$ analysis was then used (Markey et al. 2007). The ${ }^{187} \mathrm{Re}$ and ${ }^{187} \mathrm{Os}$ concentrations were determined by isotope dilution mass spectrometry using Carius-tube, solvent extraction, anion chromatography, and negative thermal ionization mass spectrometry techniques. The isotopic analysis used a ThermoScientific Triton mass spectrometer by Faraday collector. Total procedural blanks for Re and Os are less than $<1$ picograms and 0.1 picograms, respectively, which are insignificant in comparison to the Re and Os concentrations present. The Reference Material 8599 Henderson molybdenite (Markey et al. 2007) is routinely analyzed as a standard, and during the past five years returned an average Re-Os date of $27.78 \pm 0.07 \mathrm{Ma}(\mathrm{n}=15)$, indistinguishable from the Reference Age Value of $27.66 \pm 0.1$ $\mathrm{Ma}$ (Wise and Watters 2011). The ${ }^{187} \mathrm{Re}$ decay constant used is $1.666 \times 10^{-11} \mathrm{a}^{-1}$ (Smoliar et al 1996). For the $\mathrm{K} /$ Ar dating, two portions of each sample $(8-16 \mathrm{mg}$ and $\approx 30 \mathrm{mg}$ ) were weighed. A small quantity of $\mathrm{CuO}$ (approximately $0.1 \mathrm{mg}$ ) was added to the lighter portion. This sample was then wrapped in an Al-foil and proceeded to radiogenic argon measurement. The heavier portion was weighted directly on platinum evaporator and used for potassium measurement.Radiogenic argon measurements were performed on $\mathrm{Nu}$ Instruments Noblesse multicollector noble-gas spectrometer (NG 039). The Al-foil wrapped portions was melted in a double-vacuum resistant crucible at $\approx 1200{ }^{\circ} \mathrm{C}$. Pure ${ }^{38} \mathrm{Ar}$ produced by the Institute for Inorganic and Physical Chemistry of Bern University was used as the spike. $\mathrm{CuO}$ added to the samples enhances the oxidation of organic matter during this step. Titanium sponge acted as a sublimation getter and was always put to the place of the reactor where samples are heated. This was the first cleaning level of gases extracted from the samples. The final purification of argon was carried out in an isolated section of the line by a warm getter pump (D-100, SAES Getters), monitored not to release additional argon atoms (after installation it was activated for $12 \mathrm{~h}$ ). Small portions of gas aliquot released from the sample (ca. 1\%) were then measured at least three times by opening and closing
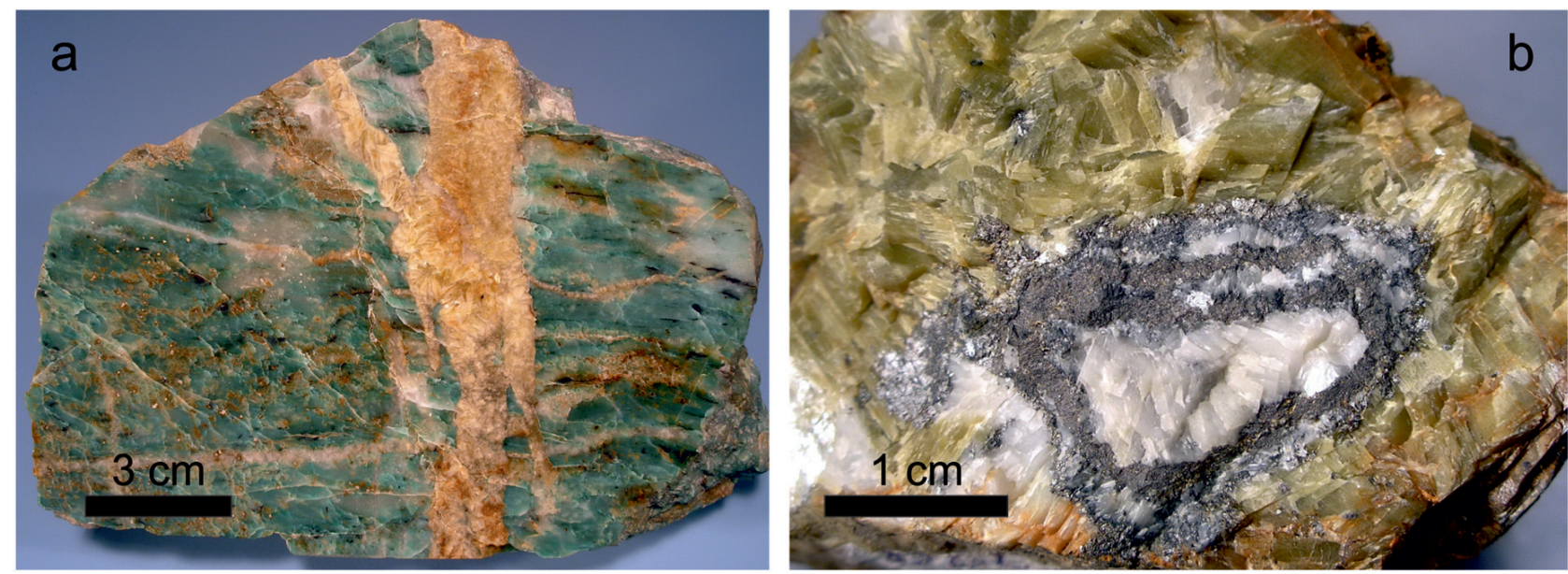

Fig. 3a - Fuchsite-rich rocks with veinlets of siderite. b - Coarse-grained siderite (brownish) and ankerite (white) with gersdorffite (metallic grey) mineralisation. Jóremény adit. Both photographs courtesy of D. Peterec. 
valves of the preparatory line in a certain sequence. Blank measurements were performed after every sample and confirmed that released radiogenic ${ }^{40} \mathrm{Ar}$ for every sample was above $99.5 \%$. Every day, the ${ }^{40} \mathrm{Ar} /{ }^{36} \mathrm{Ar}$ and ${ }^{40} \mathrm{Ar} /{ }^{38} \mathrm{Ar}$ ratios are measured for air sample aliquots, delivered from a calibrated air pipette. Based on this results ${ }^{40} \mathrm{Ar} /{ }^{36} \mathrm{Ar}$ and ${ }^{40} \mathrm{Ar} /{ }^{38} \mathrm{Ar}$ ratios were corrected for instrument mass fractionation and detector efficiencies assuming atmospheric ratios of $\left({ }^{40} \mathrm{Ar} /{ }^{36} \mathrm{Ar}\right)$ air $=298.57$ and $\left({ }^{40} \mathrm{Ar} r{ }^{38} \mathrm{Ar}\right)$ air $=1583.52$ (Lee et al. 2006). The amount of the original aliquot of ${ }^{38} \mathrm{Ar}$ spike was determined by measuring international standard GL-O glauconite, performed every day. For this series of samples $1 \sigma$ for GLO was $0.7 \%$ (13 samples). Standard age errors were calculated from the law of error propagation, also taking these values into account.The potassium contents were measured using Sherwood Model 420 flame photometer on HF dissolved samples. The maximum error of this measurement was estimated to be equal $0.03 \% \mathrm{~K}$. Based on six measurements, $\mathrm{K}$ content in GL-O glauconite was slightly higher: $6.61 \pm 0.02 \%$, than that of the standard: $6.56 \pm 0.06 \%$ (Odin 1982). LP-6 biotite has a slightly lower amount of K: $8.27 \pm 0.022 \%$ (4 measurements) comparing to reference value: $8.33 \pm 0.03 \%$ (Odin 1982). Both measured standards are within reference ranges assuming $0.03 \% \mathrm{~K}$ error.

\section{Results}

\subsection{Laboratory and field observations}

\subsubsection{Macroscopic observations}

Samples collected for this work are either fuchsite-rich country rocks or hand specimens from ore veins, collected in old mines. Samples from both old dumps and debris were avoided as much as possible because their origin and association with the ore veins are difficult to ascertain. Various kinds of metapelites (phyllite) and, less frequently, also metasandstone, with intercalations of metamorphosed mafic volcanic to volcanoclastic rocks of the Northen Gemeric Unit, are predominant host rocks of the mineralized veins.

The fuchsite-rich rocks are massive, fine-grained, distinctly green rocks that form thick (tens of meters) alteration haloes. They are not necessarily directly associated with the ore veins. If intermingled with hydrothermal siderite or ankerite, the carbonates are clearly younger than the fuchsite-rich rocks (Fig. 3a).The ore veins form tabular bodies and lenses, with a thickness of up to $1 \mathrm{~m}$. Over a distance of a few meters, however, the thickness may change drastically, sometimes to only a few millimetres filled by greyish clay. The veins are usually accompanied by a splintery rim of black, carbonaceous
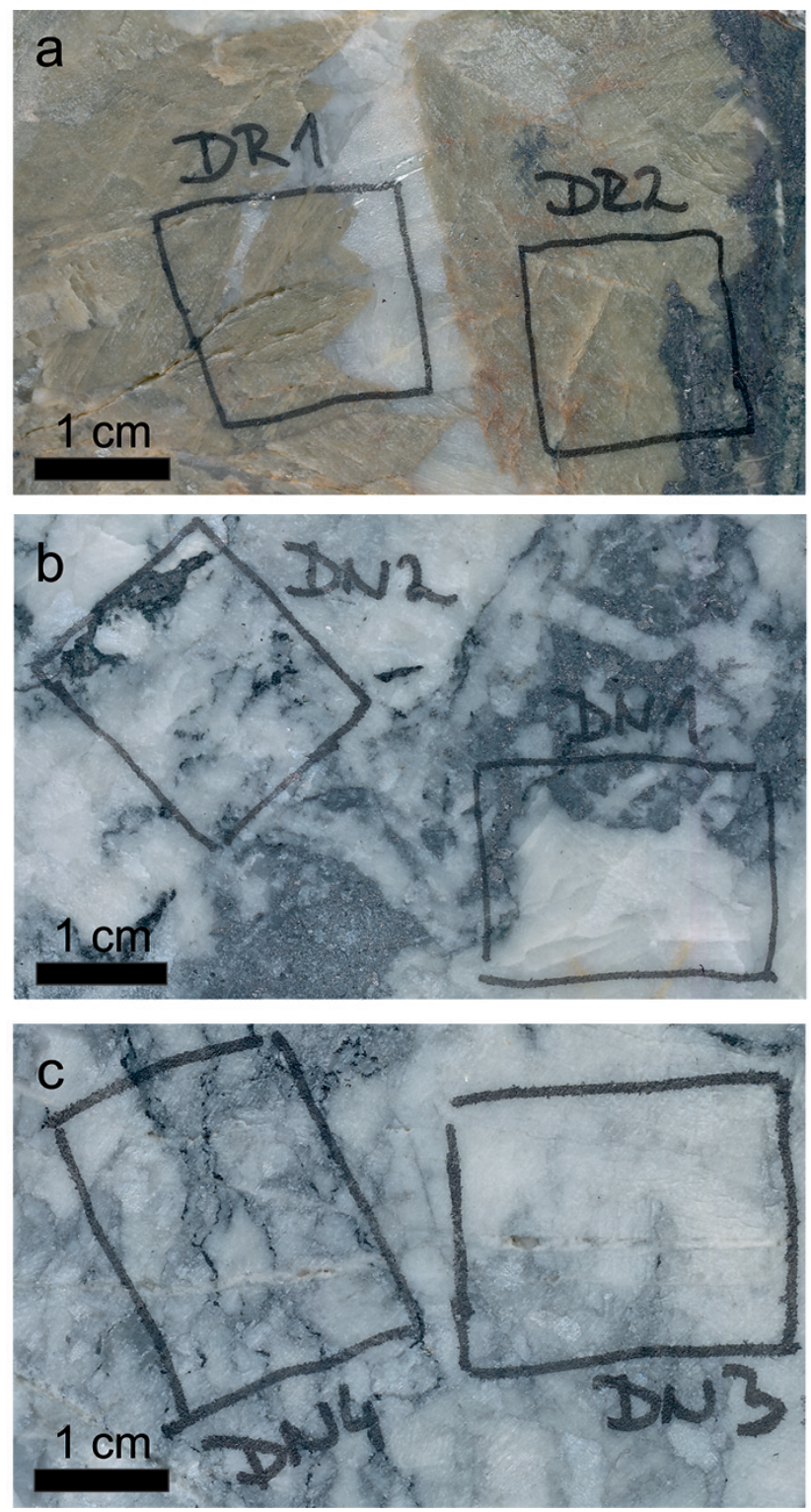

Fig. 4 Sawn slabs of samples from Dobšiná. The boxes show positions of the sections used for dating. a - Siderite (brownish, Sid I) cut by an ankerite (white, Ank I) veinlet. The metallic grey mineralisation consists of $\mathrm{Ni}$-Fe-Co sulfarsenides. $\mathbf{b}, \mathbf{c}$ - Ankerite (Ank I) with dispersed ore mineralization.

matter. The main minerals of the veins are carbonates, either siderite or ankerite. Siderite is especially common in the lower parts of the mineralized zone (Remény adit) and occurs there together with ankerite. In the higher parts (Zemberg, Jóremény), siderite is scarce. If they are found together, siderite is older than ankerite (Fig. 4a). The Ni-Fe-Co sulfarsenides are usually dispersed in the carbonates (Figs. $4 \mathrm{a}-\mathrm{c}$ ), localized in small veinlets or zones near the contact of the veins with the host rocks. The $\mathrm{Ni}-\mathrm{Fe}-\mathrm{Co}$ sulfarsenides are younger than the main carbonate mass (Fig. 3b). They are hosted by both types of carbonates but, it some cases, whitish anker- 
itic carbonate appears to be even younger than the ore minerals. A common, although a not volumetrically abundant component of the veins is quartz with tourmaline, chlorite, and albite. These minerals form pockets in the carbonates, but a precise temporal relationship to siderite, ankerite, and ore minerals was challenging to determine. The uppermost portions of the veins at the Kruhová (Gugl) hill contain siderite, baryte, and cinnabar. The relationship of these minerals to the main mineralization is not clear because they can be observed only as hand specimens in shallow pits.

\subsubsection{Structural observations}

Structural observations were carried out only in the abandoned Remény adit close to Dobšiná town because of its accessibility at the time of this study. Data for geometrical and structural analysis were obtained from the main mineralized zone emplaced in the Lower Palaeozoic metapelites in the adit. In this site, the geometry of the mineralized zone is different from other mineralized localities close to Dobšiná. In the broader area, the mineralized veins generally strike W-E with southward inclination. In the Remény adit, the mineralized structures can be roughly divided into two geometrically different groups. The main zone has the same strike as the other zone in the broader area of Dobšiná, but the dip is northwards (Fig. 5a). This relatively older structure is intersected by most probably slightly younger vein system with the NW-SE direction with the dip south-westwards (Fig. 5b).

The thickness of the main mineralized zone varies from several centimetres to several decimetres. It is a mylonite zone with shallow to medium inclination, with uniform both strike and dip in the entire accessible and observable length in the Reméy adit. The measured structured along the mylonite zone refer to an extensional tectonic regime with the orientation of the principal minimal stress axis $\left(\sigma_{3}=185 / 04^{\circ}\right)$ in the NNE-SSW direction and subvertical principal maximal stress axis $\left(\sigma_{1}=066 / 83^{\circ}\right)$. The mineralized mylonite zone generally conforms to the Variscan?Alpine metamorphic foliation and the slight variations in its dip are caused by younger folding. It is possible to assume that the mylonite zone was formed as a heterogeneous structure. However, a further detailed structural investigation is needed. Firstly, the mylonite zone could also be formed by the compressional tectonic regime (Early Cretaceous) and later (Mid- to Late Cretaceous) was overprinted by a younger low-angle normal fault mechanism. Unfortunately, limited access to the structure did not allow us more detailed structural research.

The younger mineralized veins are generally thinner and less significant. The veins are steeper than the older mineralized mylonite zone and were formed during an extensional tectonic regime with the orientation of the principal minimal stress axis $\left(\sigma_{3}=207 / 02^{\circ}\right)$ in the NE-SW direction and subvertical principal minimal stress axis
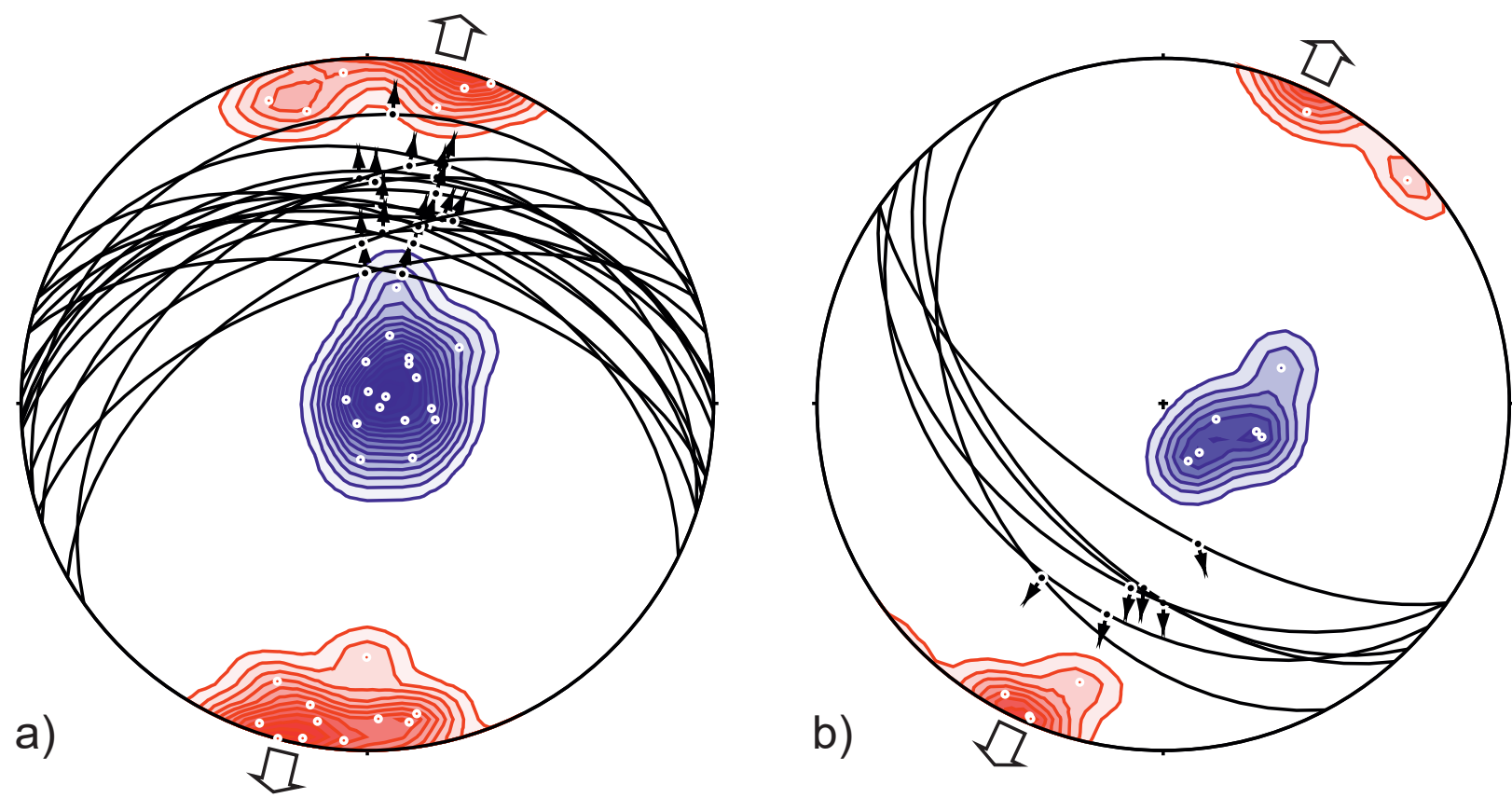

Fig. 5 Stereograms of observed mineralized structures with movement directions in the Remény adit near Dobšiná. a - great circles and movement trajectories in the main mineralized zone; $\mathbf{b}$ - great circles and movement trajectories of the younger structures than the main mineralized zone. Note: the planar structures are drawn as the great circles, and the movement trajectories (lineation on that planes) are represented by arrows. The compressional area with calculated principal compressional stress axes $\left(\sigma_{1}\right)$ is depicted by red contours and dots. The tensional area with calculated principal extensional axes $\left(\sigma_{3}\right)$ is shown by blue. Stereograms use Lambert projection, lower hemisphere. 
Tab. 2 Representative chemical compositions of carbonates from Dobšiná (in wt. \%) in the samples used in this work.

\begin{tabular}{lcccccr}
\hline & Sid I & Sid II & $\begin{array}{c}\text { Siderite } \\
\text { (disseminated) }\end{array}$ & Ank I & Ank II & Ank III \\
\hline $\mathrm{FeO}$ & 48.18 & 42.71 & 46.63 & 17.10 & 12.48 & 16.06 \\
$\mathrm{MnO}$ & 2.18 & 0.59 & 3.16 & 2.63 & 0.95 & 2.05 \\
$\mathrm{MgO}$ & 4.52 & 9.65 & 5.31 & 6.91 & 10.71 & 7.66 \\
$\mathrm{CaO}$ & 0.19 & 1.41 & 0.35 & 26.63 & 28.41 & 27.61 \\
$\mathrm{BaO}$ & $<$ D.L. & $<$ D.L & $<$ D.L. & $<$ D.L. & $<$ D.L. & $<$ D.L. \\
$\mathrm{SrO}$ & $<$ D.L. & $<$ D.L. & <D.L. & <D.L. & <D.L. & $<$ D.L. \\
\hline Total & 55.20 & 54.46 & 55.46 & 53.42 & 52.68 & 53.51 \\
\hline
\end{tabular}

$<$ D.L. - below detection limit

$\left(\sigma_{1}=109 / 73^{\circ}\right)$. These younger veins disrupt the Variscan?Alpine metamorphic foliation and Alpine mineralized aforementioned mylonite zone. According to the crosscut criteria, the faulting and mineralization process have to be younger than the Gemeric cleavage fan. Conditionally, it could be linked with the exhumation process in the Gemeric Unit. However, it is still not entirely clear whether the movement in these two zones is directly related to the mineralization process or it is the subsequent process of faulting in the Gemeric Unit or both.

\subsubsection{Observations in optical and electron microscope}

Back-scattered electron (BSE) images (Fig. 6) and WDS analyses (Tab. 2, Fig.7a) distinguished multiple generations of ankerite (Ank I-III) and siderite (Sid I and II). Ankerite I (Ank I) is the dominant carbonate phase in all samples (Figs. 3b, 4) and shows a compositional range of 15.6-21.2 mol. \% MgO, 47.0-53.3 mol. \% $\mathrm{CaO}$, 21.5-29.1 mol. \% FeO and 3.0-5.0 mol. \% MnO.

Ankerite II (Ank II) forms veinlets (hundreds of micrometres, Fig. 6a) in Ank I. The compositional range of Ank II is 25.1-29.1 mol. \% MgO, 51.3-55.2 mol. \% CaO, 15.0-20.2 mol. \% FeO and 1.1-1.7 mol. \% $\mathrm{MnO}$. In general, Ank II has less Fe than Ank I (mean concentration Ank $\mathrm{I}_{\mathrm{Fe}}=26.8$ mol. \% vs Ank $\mathrm{II}_{\mathrm{Fe}}=18.1$ mol. \%) and more $\mathrm{Mg}$ (mean concentration Ank $\mathrm{I}_{\mathrm{Mg}}=$ 18.6 mol. \% vs Ank $\mathrm{II}_{\mathrm{Mg}}=27.7 \mathrm{~mol}$. \%). Some Mg/Carich compositions might violate compositional rules for carbonate-nomenclature and therefore could be labelled as dolomite or Fe-dolomite. However, those compositions only represent minor portions and are texturally not isolated and therefore are part of the corresponding ankerite stage.

Ankerite III (Ank III) can be found as veins and fractures cutting through Ank I, Ank II, and siderite (Fig. 6b). The comffite, aspy $=$ arsenopyrite

$<$ D.L. - below detection limit positional range of Ank III is 19.8-20.8 mol. \% $\mathrm{MgO}$, 52.2-53.0 mol. \% CaO, 23.5-24.4 mol. \% FeO, and 2.7$3.7 \mathrm{~mol}$ \% $\mathrm{MnO}$. This carbonate is homogeneous when compared to Ank I and II. It is comparable to carbonate chemistry of Ank I (more Fe and less Mg than Ank II).

Siderite in the investigated samples can be found as massive coarse-grained siderite in carbonate-sulfarsenide veins (Figs. 3, 4a, 6c) or as siderite in the quartz-fuchsite rocks (Figs. 3a, 6e). The main mass of vein siderite is denoted as Sid I and has a compositional range of 11.0-16.4 mol. \% $\mathrm{MgO}, 0.1-1.0$ mol. \% CaO, 78.4-83.7 mol. \% FeO, and 2.8-5.6 mol. \% MnO. Siderite from the quartz-fuchsite rocks has a similar composition of 12.0-24.1 mol. \% MgO, 0.2-1.4 mol. \% CaO, 70.7-82.8 mol. \% FeO, and 4.2-6.1 mol. \% MnO. We assume that this siderite is also Sid I and was brought into these rocks during the siderite sub-stage.

Later siderite, denoted as Sid II, is found is thin veinlets populated by grains and crystals of $\mathrm{Ni}-\mathrm{Fe}-\mathrm{Co}$ sulfarsenides or as rims around these minerals (Fig. 6c). The compositional range of Sid II is 23.7-29.7 mol. \% $\mathrm{MgO}, 0.8-6.4$ mol. \% $\mathrm{CaO}, 65.5-72.5$ mol. \% FeO, and $0.5-1.8 \mathrm{~mol}$. \% MnO. The results of all WDX spot analyses on carbonates can be seen in the electronic supplementary table S1.1.

\subsubsection{Ore mineralization}

Optical microscopy and BSE images suggest that the ore mineralization, represented mostly by $\mathrm{Ni}-\mathrm{Fe}-\mathrm{Co}$

Tab. 3 Representative chemical compositions of sulfarsenides and arsenides from Dobšiná (in wt. \%) from the samples used for geochronological dating in this work. Mineral abbreviations: $g d f=$ gersdor-

\begin{tabular}{llllll}
\hline & $\begin{array}{l}\text { DR2 } \\
\text { gdf }\end{array}$ & $\begin{array}{l}\text { DN3 } \\
\text { aspy }\end{array}$ & $\begin{array}{l}\text { DN3 } \\
\text { gdf }\end{array}$ & $\begin{array}{l}\text { DN2 } \\
\text { gdf }\end{array}$ & $\begin{array}{l}436 \\
\text { gdf }\end{array}$ \\
\hline $\mathrm{Sb}$ & 0.14 & $<$ D.L. & 0.09 & 0.09 & 0.09 \\
$\mathrm{~S}$ & 13.94 & 19.18 & 15.56 & 11.37 & 15.74 \\
$\mathrm{As}$ & 51.67 & 45.51 & 49.43 & 54.83 & 49.87 \\
$\mathrm{Co}$ & 0.60 & $<$ D.L. & 7.09 & 4.11 & 2.48 \\
$\mathrm{Ni}$ & 32.17 & 0.09 & 20.82 & 26.13 & 29.47 \\
$\mathrm{Fe}$ & 1.35 & 34.62 & 7.12 & 2.99 & 1.86 \\
\hline Total & 99.87 & 99.40 & 100.11 & 99.52 & 99.50 \\
\hline
\end{tabular}



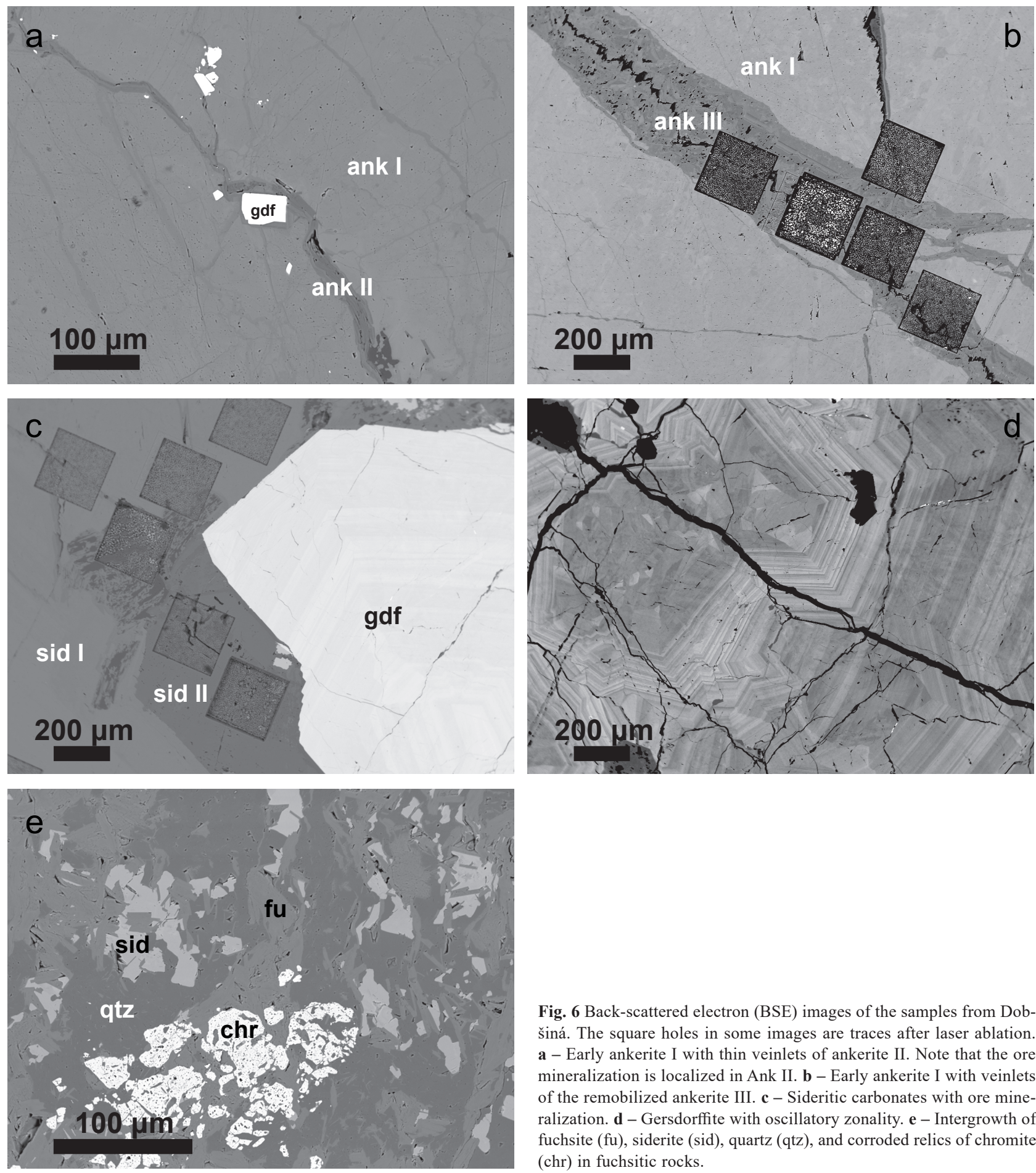

Fig. 6 Back-scattered electron (BSE) images of the samples from Dobšiná. The square holes in some images are traces after laser ablation. a - Early ankerite I with thin veinlets of ankerite II. Note that the ore mineralization is localized in Ank II. b - Early ankerite I with veinlets of the remobilized ankerite III. $\mathbf{c}$ - Sideritic carbonates with ore mineralization. d-Gersdorffite with oscillatory zonality. $\mathbf{e}-$ Intergrowth of fuchsite (fu), siderite (sid), quartz (qtz), and corroded relics of chromite (chr) in fuchsitic rocks.

sulfarsenides, is hosted by all carbonates except for the late Ank III. The ore minerals found are arsenopyrite and Ni-rich sulfarsenides, mainly gersdorffite and members of the gersdorffite-arsenopyrite solid-solution (Tab. 3, Fig. 7b). Chemical composition of ore minerals in the system $\mathrm{Ni}-\mathrm{Fe}-\mathrm{Co}-\mathrm{As}-\mathrm{S}$ is defined by a great chemical variability and abundant polymorphism. Such variability is also observed in the samples from Dobšiná (Kiefer et

al. 2017), but it is not bound to a particular mineralization stage but rather a general observation for all samples.

Gersdorffite occurs as small disseminated crystals in Ank II (Fig. 6a), as large strongly zoned and often highly fractured assemblages in Ank I and siderite (Figs. 3b, 6c, d) and it is the most common ore mineral in the investigated samples. The compositional range of gersdorffite is $0-0.5$ wt. \% $\mathrm{Sb}, 10.8-19.8$ wt. \% 

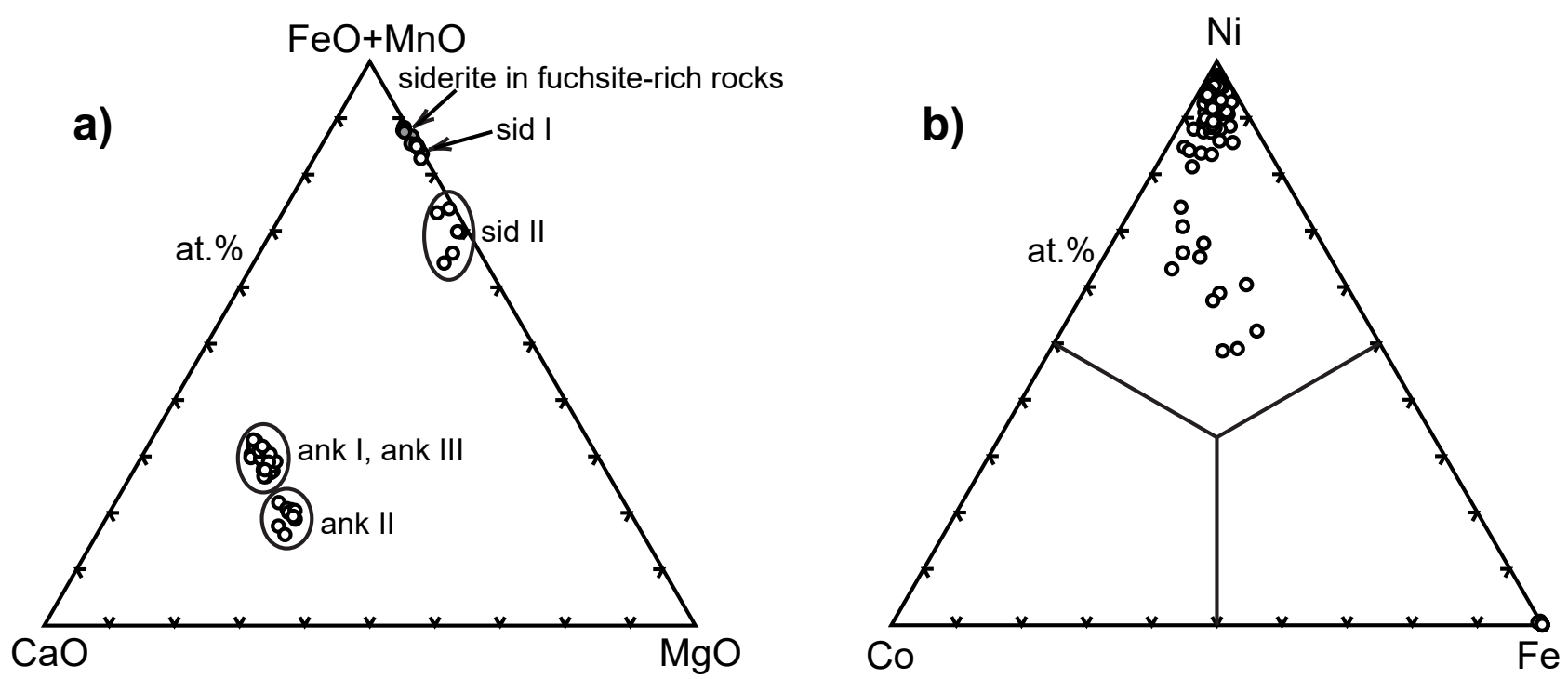

Fig. 7 Triangular diagrams showing $\mathbf{a}-$ the composition of the generations of hydrothermal carbonates and $\mathbf{b}-\mathrm{composition}$ of the Ni-Fe-Co sulfarsenides in the samples used for dating.

S, 43.2-63.1 wt. \% As, $0.3-12.7$ wt. \% Co, $0-0.03$ wt. $\% \mathrm{Cu}, 13.8-34.2$ wt. $\% \mathrm{Ni}$, and $0.4-11.7$ wt. $\% \mathrm{Fe}$, highlighting the variations from almost ideal stoichiometries (e.g., $\mathrm{Ni}_{0.94} \mathrm{Co}_{0.04} \mathrm{Fe}_{0.01} \mathrm{As}_{1.00} \mathrm{~S}_{1.01}$ ) to substantial deviations, therefore (e.g., $\mathrm{Ni}_{0.54} \mathrm{Co}_{0.21} \mathrm{Fe}_{0.28} \mathrm{As}_{1.04} \mathrm{~S}_{0.94}$, $\mathrm{Ni}_{0.86} \mathrm{Co}_{0.07} \mathrm{Fe}_{0.08} \mathrm{As}_{1.18} \mathrm{~S}_{0.82}$ or $\left.\mathrm{Ni}_{0.98} \mathrm{Co}_{0.03} \mathrm{Fe}_{0.22} \mathrm{As}_{1.52} \mathrm{~S}_{0.45}\right)$ including some high-As compositions corresponding to rammelsbergite/krutovite-like stoichiometries.Arsenopyrite is a minor phase and only occurs as small disseminated crystals in Ank II together with gersdorffite. The mineral chemistry of arsenopyrite is relatively constant and approaches the mean stoichiometry of $\mathrm{Fe}_{1.02} \mathrm{As}_{1.00} \mathrm{~S}_{0.98}$. The results of all WDX spot analyses on sulfarsenides and arsenides can be seen in the electronic supplementary table S1.2.

\subsection{Geochronology}

\subsubsection{U/Pb LA-SF-ICP-MS dating on carbonates}

Nine samples (DR1-DR4, DN1DN4, DBK1) were selected for the $\mathrm{U} / \mathrm{Pb}$ dating, but only four gave one or two statistically meaningful regression lines with sufficient variation in the $\mathrm{U} / \mathrm{Pb}$ to calculate lower intercept ages. Representative Tera-Wasserburg diagrams are shown in Fig. 8. Three samples (DN1, DR2, and DN3) gave older and younger ages and one sample (DN2) only one younger age. The

Tab. 4 Geochronological data for the carbonate-sulfarsenide veins from Dobšiná.

\begin{tabular}{lccc}
\hline sample & method & age $(\mathrm{Ma})$ & mineral analyzed \\
\hline \multirow{2}{*}{ DN1 } & U/Pb LA-SF-ICP-MS & $145.3 \pm 5.1$ & Ank I \\
& & $20.7 \pm 5.3$ & Ank III \\
DN2 & U/Pb LA-SF-ICP-MS & $27.4 \pm 6.2$ & Ank III \\
& & $114 \pm 24$ & Ank I \\
DN3 & U/Pb LA-SF-ICP-MS & $29.5 \pm 5.7$ & Ank III \\
& & & Sid I \\
DR2 & U/Pb LA-SF-ICP-MS & $118 \pm 10$ & fuchsite \\
Pr1 & K/Ar & $109.5 \pm 3.4$ & fuchsite \\
Pr2 & K/Ar & $108.6 \pm 5.9$ & gdf \\
436 & Re/Os & $95.7 \pm 1.2$ & gdf \\
\hline
\end{tabular}

Tab. 5 Mineralogical composition and geochronological data for the fuchsite samples from Dobšiná

\begin{tabular}{|c|c|c|c|}
\hline sample & Pr1 repetition & Pr1 & Pr2 \\
\hline \multicolumn{4}{|c|}{ mineralogical composition (all data in wt. \%) } \\
\hline quartz & 45 & & 59 \\
\hline sierite & 11 & & 2 \\
\hline kaolinite & & & 2 \\
\hline mica $2 M_{1}$ (fuchsite) & 44 & & 37 \\
\hline total & 100 & & 100 \\
\hline \multicolumn{4}{|l|}{$\mathrm{K} / \mathrm{Ar}$ isotopic age data } \\
\hline mass (mg) & 16.18 & 8.19 & 8.85 \\
\hline $\mathrm{K}_{2} \mathrm{O}(\%)$ & 4.82 & 4.82 & 4.68 \\
\hline $\mathrm{K}(\%)$ & 4.00 & 4.00 & 3.88 \\
\hline${ }^{40} \mathrm{Ar}^{*}(\%)$ & 43 & 66 & 42.3 \\
\hline age (Ma) & 109.5 & 109.6 & 108.6 \\
\hline $2 \sigma(\mathrm{Ma})$ & 5.8 & 3.9 & 5.9 \\
\hline
\end{tabular}



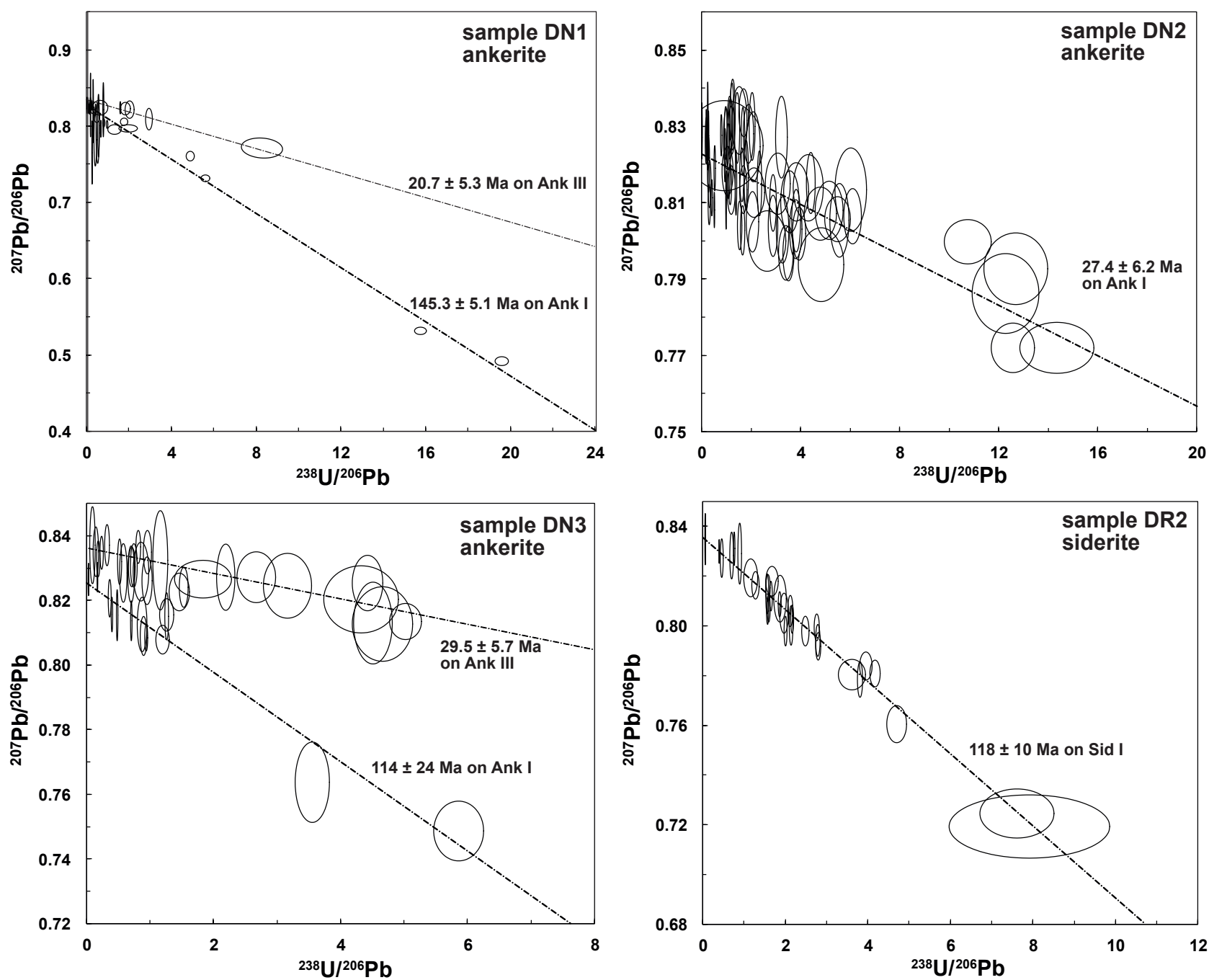

Fig. 8 Tera-Wasserburg diagrams for the carbonate samples dated in this study by LA-SF-ICP-MS. Note, that for display reasons, plots showing young and old isochrones are merged from two plots.

older isochron ages vary between $145 \pm 5 \mathrm{Ma}$ and $114 \pm 24$ Ma. All old ages have been acquired on Ank I and Sid I (Tab. 4). The three younger isochron ages vary between 20.7 and 29.5 Ma and are assigned to Ank III (Tab. 4). The $\mathrm{U}$ and $\mathrm{Pb}$ concentrations as well as the calculated isotopic ratios of the four samples DN1, DN2, DN3 and DR2 can be seen in the electronic supplementary table S2.K/Ar dating of fuchsite

Two samples from the wall-rock alteration were chosen for K/Ar-dating. A preliminary investigation by XRD showed that both samples contained mostly quartz and fuchsite and to a lesser amount siderite and kaolinite (Tab. 5). Both samples gave similar ages averaging at 109 Ma (Tabs 4 and 5).

\subsubsection{Re/Os dating of gersdorffite}

Nine representative gersdorffite samples were preanalyzed or analyzed but only the sample 436 yielded an age, with a value of $95.7 \pm 1.2 \mathrm{Ma}$ (Tab. 6). The age uncertainty is quoted at $2 \sigma$ level and includes all known analytical uncertainty, including a $\approx 0.31 \%$ uncertainty in the decay constant of ${ }^{187} \mathrm{Re}$. The gersdorffite sample analysis was replicated using a larger sample aliquot and yielded a more precise age of 93.6 $\pm 0.9 \mathrm{Ma}$, which lies within the uncertainty of the first analysis. To our best knowledge, this datum is the first Re/Os age obtained from gersdorffite.

\section{Discussion}

\subsection{Precipitation sequence of hydrothermal minerals in Dobšiná}

The precipitation sequence of hydrothermal minerals in Dobšiná was established by Halahyjová-Andrusovová (1959) on many samples from the old mines that were 
Geochronological constraints on the carbonate-sulfarsenide veins in Dobšina

accessible during the exploration activities in the 1950s. The sequence published by Halahyjová-Andrusovová (1959) can be augmented by observations done in this work, the work of Kiefer et al. (2017), and especially correlation with siderite-sulfide deposits in the Gemeric Unit (Varček 1985; Chovan et al. 1994; Hurai et al. 2008). The sequence constructed here (Fig. 9) focuses mainly on the $\mathrm{Ni}-\mathrm{Fe}-\mathrm{Co}$ veins and neglects other important ores found in the Gemeric Unit, e.g., the quartz-sulfide phase with stibnite (see Fig. 5 in Hurai et al. 2008).

All these authors agree that fuchsite and the associated minerals represent the oldest-fuchsite stage, either in Rudňany (cf. Rojkovič 1977) or elsewhere. In our samples from Dobšiná, siderite-ankerite veinlets penetrate the fuchsitic rocks (Fig. 3a), thus confirming the observations from Rudňany. The following siderite sub-stage (Hurai et al. 2008) is mineralogically simple, with dominant siderite and subordinate ankerite. The baryte sub-stage is prominently developed at some deposits, for example in Rudňany, but not in Dobšiná. Baryte, together with siderite and cinnabar, does occur in the highest portions of the veins in Dobšiná. The hand specimens, recovered from shallow surface pits at the Kruhová hill do not allow the placement of this baryte into the precipitation sequence. We assume, however, that its position in the precipitation sequence is the same as in the Rudňany deposit.

The quartz-tourmaline stage is devoid of ore minerals and developed locally. Owing to the common occurrence of monazite, this stage has been a subject of previous geochronological work (e.g., Hurai et al. 2015) and provides an important marker that separates, in time, the older (fuchsite, siderite, baryte) and younger (sulfide) stages.Numerous observations in the old mines suggest that ankerite is generally younger than siderite. This

Fig. 9 Precipitation sequence of minerals from Dobšiná. Compiled from the work of Halahyjová-Andrusovová (1959), Varček 1985, Chovan et al. 1994, Hurai et al. 2008, Kiefer et al. 2017, and this work.

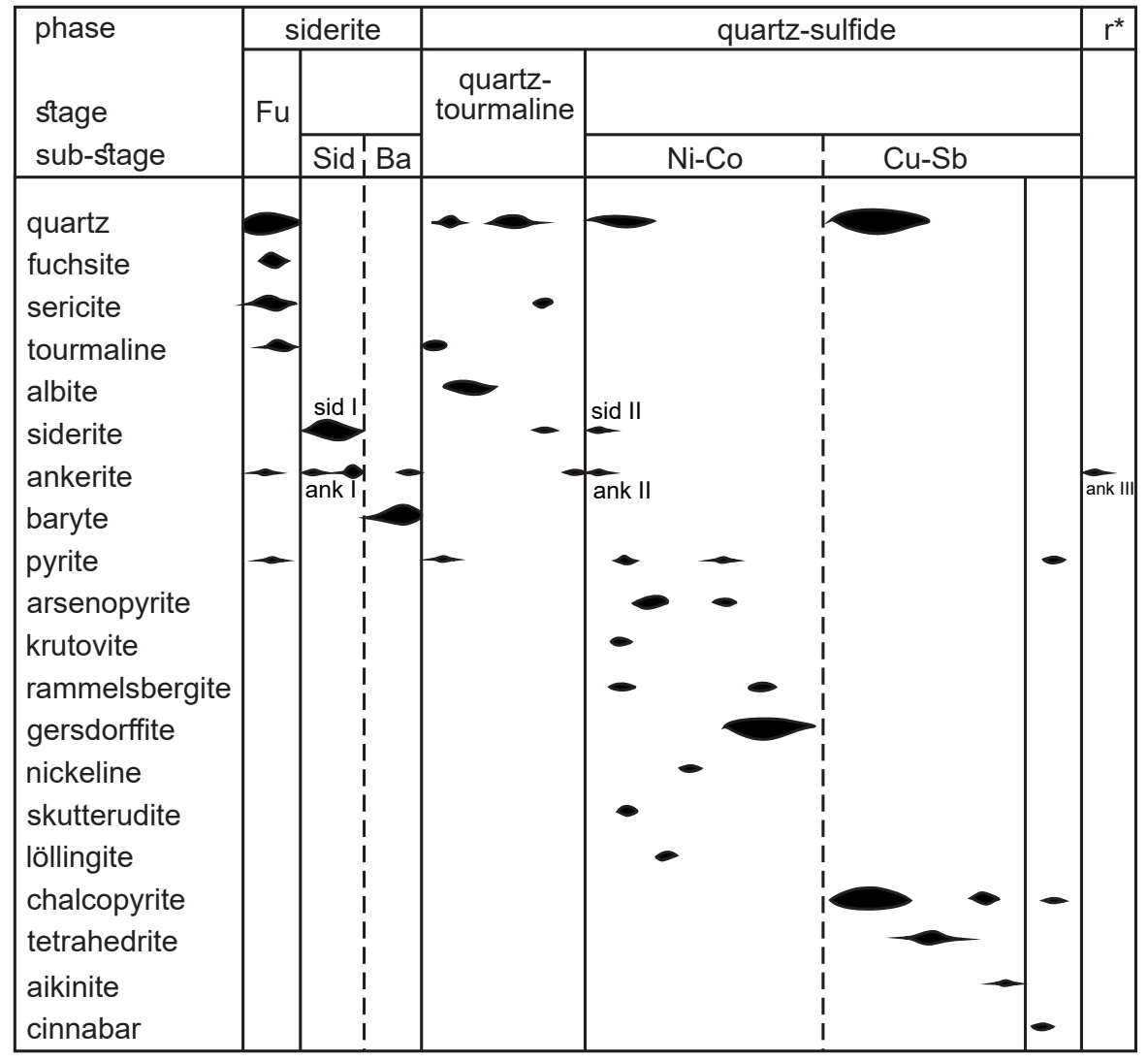

* remobilization phase conclusion also agrees with the earlier studies; Hurai et al. (2008) assert that the main carbonate associated with the sulfide stage is ankerite (Fig. 3 b). Ni-Fe-Co arsenides are scarce minerals in the ore deposits in the Gemeric Unit, except Dobšiná and some veins at the Rudňany and Rožňava deposits (Koděra et al. 1990). If considered in the precipitation sequence, they are usually placed early in the quartz-sulfide stage (e.g., Rojkovič 1977; Chovan et al. 1994). Their chemical and mineralogical evolution in Dobšiná was described in detail by Kiefer et al. (2017), but there is no reason, either from that or the current work, to assume that they were formed in several separate hydrothermal pulses or events. The $\mathrm{Ni}-\mathrm{Fe}-\mathrm{Co}$ arsenides are often crushed and healed by younger $\mathrm{Cu}$ sulfides, either chalcopyrite or tetrahedrite. A simple placement of the arsenides with the later $\mathrm{Cu}$ sulfides in one stage, without indication of the tectonic damage, is therefore questionable. We, therefore, distinguish the $\mathrm{Ni}-\mathrm{Co}$ and $\mathrm{Cu}-\mathrm{Sb}$ (chalcopyrite-tetrahedrite) mineralizations as two separate substages of the quartz-sulfide stage (Fig. 9). 


\subsection{Age constraints on the fuchsite stage}

There is no doubt that fuchsite, together with quartz and carbonates, constitute the oldest mineralization stage in Dobšiná and Rudňany (cf. Rojkovič 1977; Hurai et al. 2008). Fuchsite-carbonate-quartz rocks have also been described from several other sites in the Gemeric Unit (Roztoky, Bindt, Stará Voda, Nálepkovo, Mlynky, Mišíkova skala, Košické Hámre, Hnilec) and interpreted as a final product of metasomatic alteration of ultrabasic or basic rocks by $\mathrm{CO}_{2}$-rich hydrothermal fluids (Ivan 1982)

Fuchsite from the Gemeric Unit has been subjected to several K/Ar geochronological studies. The value determined from Dobšiná (Augustín quarry, Malá Vlčia dolina) is $190.8 \mathrm{Ma}\left(0.83 \% \mathrm{~K}_{2} \mathrm{O}\right)$ (Cambel et al. 1980). This work reported $\mathrm{K} / \mathrm{Ar}$ age determinations from metamorphic rocks in the broader area of Dobšiná, some of them with clear signs of retrograde metamorphism. These ages scatter considerably and are 273, 258, 227, $154 \mathrm{Ma}$. Fuchsite was also dated in Rudňany to $210 \pm 2 \mathrm{Ma}(1.11 \%$ $\mathrm{K}_{2} \mathrm{O}$ ) (Bagdasaryan et al. 1977), later revisited and revised to $205 \mathrm{Ma}$, with another datum of $144 \mathrm{Ma}$ (Cambel et al. 1990). The significance of these scattered values in comparison with the newer geochronological data is questionable. Our K/Ar ages for fuchsite of 109 and $110 \mathrm{Ma}\left(4.68-4.82 \% \mathrm{~K}_{2} \mathrm{O}\right)$ (Tab. 5 and Fig. 10) are distinctly younger than the previously published values and also contradict the $\mathrm{U} / \mathrm{Pb}$ age of the carbonates (Tab. 4) which are texturally younger than fuchsite (Fig. 3a). Low $\mathrm{K}$-amounts in previous measurements can also indicate that these dates correspond to rocks containing low amounts of fuchsite. Early on, it was noted that the K/Ar ages in this area are scattered and contradictory (Hovorka and Spišiak 1981) and may have been subject to resetting during the intensive Alpine reworking (Radvanec et al. 2004). Similar ages (clustered around $100 \mathrm{Ma}$ ) were obtained by $\mathrm{Rb} / \mathrm{Sr}$ (Kovách et al. 1986) or K/Ar (Kantor and Rybár 1979) dating of sheet silicates from the Gemeric Unit. Given that fuchsite is a Cr-rich variety of muscovite, the closure temperature of $350 \pm 40^{\circ} \mathrm{C}$ (Spear and Parrish 1996) also applies to this mineral. Fuchsite from Dobšiná is a product of alteration, although not too fine-grained, and its closure temperature may lie near the lower end of the interval specified by Spear and Parrish (1996). Additionally, fluid-assisted recrystallization compared to pure temperature-controlled diffusion can be of importance, as was shown, e.g. by Tartèse et al. (2011). If taken at its face value, the $\approx 110$ Ma could be interpreted as the age of the last cooling below $\approx 320^{\circ} \mathrm{C}$ or lower, due to the influence of fluids (e.g., Villa 2015). This temperature coincides with the last hydrothermal pulses related to the crystallization of the hydrothermal carbonates (see below). This interpretation is also supported with the estimates of peak P-T conditions of the Alpine metamorphism in the Gemeric Unit of $320-350^{\circ} \mathrm{C}$ and 0.4-0.55 GPa (Faryad and Dianiška 1999). This event, correlated with the geochronological data of Dallmeyer et al. (1996), was assigned Cretaceous age (120-86 Ma) and the zircon fission-track data (Plašienka et al. 2007; Králiková et al. 2016). The meaning of the previously published, older ages remains questionable. Why, for example, are the two ages of fuchsite from one locality, Rudňany, 60 Ma apart (Cambel et al. 1990)? They may represent mixed ages of several minerals in the bulk samples used at that time. Some of the minerals may have been formed earlier than fuchsite and experienced partial Ar loss during the Alpine times (e.g., hornblende from amphibolites). Argon loss could be locally enhanced by the influence of hydrothermal fluids, promoting recrystallization, producing thus varying ages from a single locality.

\subsection{Age constraints on the carbonate minerals}

The carbonate minerals found in Dobšiná, either siderite or ankerite, formed mostly during the siderite sub-stage (Fig. 9). Among the massive vein carbonates, siderite (sid I) is usually older than ankerite (Ank I). The BSE images (Fig. 6) document repeated remobilization of carbonates, thus suggesting that their mutual relationship and assignment to a particular stage may not be straightforward.

There are no geochronological data for the hydrothermal carbonates in the Gemeric Unit. The two competing and conflicting models argue for Permian (Radvanec et al. 1994a, b, 2004; Radvanec and Grecula 2016) or Cretaceous (Hurai et al. 2002, 2008) age of these and associated minerals. They are based on geological arguments, application of geothermobarometry, and estimation of hydrothermal fluid properties and chemistry.All our results place the formation of the hydrothermal carbonates in Dobšiná to Cretaceous. Two ankerite samples gave ages of $145 \pm 5$ and $114 \pm 24 \mathrm{Ma}$ and the only siderite sample that returned an age gave $118 \pm 10 \mathrm{Ma}$. These ages mark thrusting of the Gemeric Unit onto the Veporic crystalline basement from 140 to $115 \mathrm{Ma}$ (Hurai et al. 2008, 2015; Vozárová et al. 2014). This overthrust is further constrained by the cooling of the uppermost Gemeric and overlying rocks complexes of the Meliata accretionary wedge documented by zircon (U-Th)/He ages and ZFT ages (130-90 Ma; Plašienka et al. 2007; Putiš et al. 2014; Králiková et al. 2016). Formation of the main mass of the hydrothermal siderite and ankerite appears to be confined to this crustal-scale event. The subsequent exhumation of the Gemeric Unit (115-80 Ma) was accompanied by different types of ore mineralizations, described below. Thrusting of the Gemeric Unit onto the Veporic Unit 
was also accompanied by the hydrothermal remobilization of $\mathrm{U}-\mathrm{Mo}-\mathrm{Cu}$ mineralization in the northern parts of Gemeric Unit at $130 \pm 20 \mathrm{Ma}$ (Rojkovič et al. 1993) or $124 \pm 10$ Ma (Rojkovič and Konečný 2005).

\subsection{Age constraints on the quartz-tourmaline stage}

This stage, regionally distributed in the Gemeric Unit, has been dated in the past. Monazite, an integral component of this stage, was analyzed either by electron microprobe or LA-ICP-MS. Monazite from Čučma gave ages of $120 \pm 9$ and $76 \pm 12 \mathrm{Ma}$, with a weighted average of $92 \mathrm{Ma}$ (Hurai et al. 2006). Later, Hurai et al. (2015) extracted a more precise age of $139 \pm 1$ Ma from monazite from Rožňava. There are some data on monazite from the quartz-tourmaline stage from the Tatric and Veporic units, where the results scatter broadly around $100 \mathrm{Ma}$ (Majzlan et al. 2020). Another temporal hint is the age of $131 \mathrm{Ma}$, extracted from a zircon overgrowth in the Paleozoic siliciclastic metasediments (Vozárová et al. 2013).

The CHIME age of monazite from Jedl'ové Kostol'any is $83 \pm 9 \mathrm{Ma}$, that from L'ubietová (Veporic Unit) $92 \pm 11$ and $97 \pm 9$ Ma (Ozdín 2008, 2015; Ozdín et al. 2016). At these localities, these authors consider the quartztourmaline stage with monazite to be contemporaneous with the $\mathrm{Ni}-\mathrm{Co}$ arsenide mineralization. If so, these dates would place independent constraints on the $\mathrm{Ni}-\mathrm{Co}$ sub-stage, even though not in the Gemeric Unit.According to the position of this quartz-tourmaline stage in the general precipitation sequence in the Gemeric Unit, it is younger than the siderite phase and usually older than the $\mathrm{Ni}-\mathrm{Co}$ sub-stage of the quartz-sulfide phase. Siderite and ankerite, perhaps components of the siderite stage, have been dated in this work to $145-114 \mathrm{Ma}$, with multiple remobilization events visible in the BSE images and geochronological data. Given that monazite could have also been repeatedly remobilized (cf. Hurai et al. 2006), we can only conclude that the available data fit roughly together. Exact differentiation of the ages of these two stages is thus complicated by multiple remobilization events.

\subsection{Age constraints on the $\mathrm{Ni}-\mathrm{Fe}-\mathrm{Co}$ sulfarsenides}

The carbonates Sid II and Ank II are closely associated with the $\mathrm{Ni}-\mathrm{Fe}-\mathrm{Co}$ sulfarsenides and precede their crystallization. We were not able to obtain their ages, however, because of their low U content.

In the quartz-sulfide phase in the Gemeric Unit, precipitation of the $\mathrm{Ni}-\mathrm{Fe}-\mathrm{Co}$ sulfarsenides precedes the more abundant and voluminous $\mathrm{Cu}$ sulfides (Fig. 9) (Varček 1985; Chovan et al. 1994). Such a position also agrees with the results from the Tatric and Veporic Unit (Ozdín 2003, 2008; Ozdín et al. 2016) where the $\mathrm{Ni}-\mathrm{Fe}-\mathrm{Co}$ sulfarsenides occur only locally and in small quantities.

There are no exact geochronological data for any opaque minerals of this phase. Our datum of $93.6 \pm 0.9$ $\mathrm{Ma}$ is the first numerical result that documents the age of these minerals. It places constraints not only on the Ni$\mathrm{Fe}-\mathrm{Co}$ arsenides, but also on the older quartz-tourmaline stage and the younger $\mathrm{Cu}$ sulfides. We should note that we attempted U/Pb LA-ICP-MS dating of the gersdorffite and other $\mathrm{Ni}-\mathrm{Fe}-\mathrm{Co}$ sulfarsenides. All these attempts failed because of the high $\mathrm{Pb}$ content of these minerals. As mentioned above, the $\mathrm{Cu}$ sulfides postdate the $\mathrm{Ni}$ $\mathrm{Fe}-\mathrm{Co}$ sulfarsenides. The age of the $\mathrm{Cu}$ sulfides remains unknown; the only hint is the $\mathrm{Ar} / \mathrm{Ar}$ dating of muscovite from Jedlové Kostol'any (Ozdín 2010), with the ages of $75 \pm 1$ and $75 \pm 2 \mathrm{Ma}$. This muscovite was assumed to postdate the sulfide mineralization at this locality.

\section{Conclusion}

Geochronological data from this work place the sideritesulfide veins from the Gemeric Unit in Cretaceous (Fig. $10)$, in agreement with the results and interpretations in Hurai et al. $(2002,2006,2008)$. The arguments presented there are based on $P-T$ estimates, which suggest that the mineralization formed at relatively high pressures, compatible with the overburden of crystalline rocks, PermoTriassic cover and the Jurassic (Meliata) accretionary wedge (Hurai et al. 2008). The new geochronological data disentangle the evolution of the complex, multi-stage hydrothermal systems more precisely.

The new data can be reconciled with the models of the crustal evolution of the Gemeric Unit (Lexa et al. 2003) and its thermal history (Fig. 10). The formation of the siderite stage broadly coincides with the metamorphic peak in the Gemeric Unit and the formation of the Gemeric cleavage fan (CGF), a large arcuate fan whose origin is linked to $\mathrm{N}-\mathrm{S}$ compression of the Gemeric rocks during the thrusting (Lexa et al. 2003). Continuation of the Cretaceous shortening resulted later in the formation of the Trans-Gemeric shear zone, a zone that is developed in both Gemeric and the Veporic units. Thus, at this time, these two units must have already been amalgamated. This time matches with the formation ages of some of the monazite in the quartz-tourmaline stage, the $\mathrm{Ni}-\mathrm{Fe}-\mathrm{Co}$ sulfarsenides in Dobšiná, and marginally also with the formation of the $\mathrm{Cu}$ sulfides. The $\mathrm{Cu}$ sulfides, if given the tentative Late Cretaceous age of $75 \mathrm{Ma}$, postdate the unroofing and exhumation of the Veporic Unit from beneath the Gemeric Unit. These mineralizations also date the age of the Trans-Gemeric shear zone formation (cf. Lexa et 


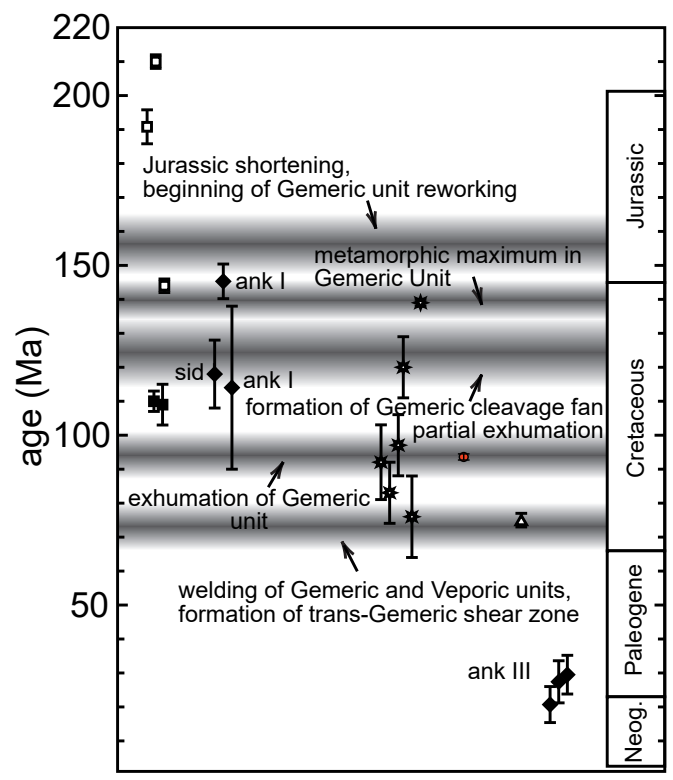

- U/Pb on carbonates, this work related to the siderite sub-stage and remobilization phase

- K/Ar on fuchsite, this work, related to the fuchsite stage

- Re/Os on gersdorffite, this work, related to the $\mathrm{Ni}-\mathrm{Co}$ sub-stage

- K/Ar on fuchsite, Dobšiná, Rudňany (Cambel et al. 1980, 1990), related to the fuchsite stage

* U/Th/Pb on monazite, Čučma, Rožňava (Hurai et al. 2006, 2015), L'ubietová, Jedlové Kostolany (Ozdín 2008, 2015, Ozdín et al. 2016), related to the quartz-tourmaline stage

• Ar/Ar on muscovite, Jedl'ové Kostolany (Ozdín 2010) perhaps related to the $\mathrm{Cu}-\mathrm{Sb}$ sub-stage

Fig. 10 Summary and review of the results of this work and earlier studies in relation to the tectono-thermal evolution of the Gemeric unit. For display reasons, the data was plotted with a horizontal offset.

al. 2003). The young, Paleogene-Neogene ages recorded by the carbonates are a product of remobilization. K/Ar data on fuchsite provide scattered, perhaps mixed ages and may indicate that the last cooling below $\approx 320^{\circ} \mathrm{C}$ occurred at $\approx 110 \mathrm{Ma}$. This datum broadly agrees with the age of the Alpine exhumation of the Gemeric Unit at 110-90 Ma (Plašienka et al. 2007; Králiková et al. 2016) and the $\mathrm{K} / \mathrm{Ar}$ ages on muscovite and biotite, interpreted as cooling ages between 110-95 Ma (Hurai et al. 2008). At $87-75 \mathrm{Ma}$, the Gemeric Unit has been shown to cool below $\approx 240^{\circ} \mathrm{C}$, the annealing temperature of zircon fission tracks (Plašienka et al. 2007). This work did not address several outstanding issues. First, no age was retrieved for the metasomatic Fe-rich carbonates, which occur in Dobšiná and were mined in much larger deposits Nižná Slaná and Kobeliarovo. In Dobšiná, these bodies are weathered so profoundly that no reasonable samples could be collected at the surface. Hence, their temporal coincidence with the vein siderite mineralization cannot be confirmed or refuted. Models from the Eastern Alps (Prochaska 2016) on similar metasomatic siderite bod- ies argue for their older - Triassic age, with formation conditions similar to those invoked by Radvanec et al. (2004). The other issue touched upon is the age of the fuchsite-carbonate-quartz alteration and the role of these rocks as suppliers of $\mathrm{Ni}$ and $\mathrm{Co}$ for the hydrothermal ores. Because of the Alpine metamorphic overprint (Faryad and Dianiška 1999), no formation ages were determined for these rocks. Such ages would be needed, however, to understand the mobility of $\mathrm{Ni}$ and $\mathrm{Co}$ in temporally distinct events, such as the fuchsite-carbonate-quartz alteration and formation of hydrothermal veins with $\mathrm{Ni}-$ $\mathrm{Fe}-\mathrm{Co}$ sulfarsenides. One must ask why only the latter produced ore minerals when $\mathrm{Ni}, \mathrm{Co}$, and $\mathrm{Fe}$ must have been mobile during alteration.

Acknowledgements. We are very thankful for the helpful comments of the handling editor Petr Jeřabek and the reviews of Jiří Sláma and one anonymous reviewer. All reviews and comments helped to improve the manuscript. We are most thankful to Mr. Š. Polgáry (Dobšiná) for great help with accessing the old mines in Dobšiná. We also thank Mr. D. Peterec for the photographs in Fig. 3 and the permission to publish them. We appreciate the cooperation with S. Honig, the company European Cobalt, and their permission to publish these data. This work was financially supported by the Deutsche Forschungsgemeinschaft grant KI 2131/2-1 (S.K., J.M.), by Slovak Research and Development Agency projects APVV-0375-12 (D.O.), APVV-0315-12, APVV-17-0170 (R.V). This is FIERCE contribution No. XX.

\section{References}

Ahlburg J (1913) The most important ore deposits in the Slovenské rudohorie Mts, Upper Hungary. Magy kir földt Intéz Évk (Budapest) 20: 327-357 (in Hungarian)

Allmendinger Rw, Cardozo NC, Fisher D (2013) Structural Geology Algorithms: Vectors \& Tensors. Cambridge University Press, Cambridge, England, pp 1-289

Árkai P, Faryad Sw, Vidal O, Balogh K (2003) Very low-grade metamorphism of sedimentary rocks of the Meliata unit, Western Carpathians, Slovakia: implications of phyllosilicate characteristics. Int J Earth Sci 92: 68-85

Bagdasaryan GP, Cambel B, Veselský J, Gukasyan RC (1977) K-Ar age determinations of the rocks from crystalline complexes of the Western Carpathians and preliminary interpretations of results. Geol Carpath 28: 219-242

BERNARD JH (1963) Polyascendent regional zoning in the metallogenic region of the Spiško-gemerské Rudohorie Mts., Czechoslovakia. In: Symposium Problems of postmagmatic ore deposition, Prague, 149-153

BöcKH H (1908) Bemerkungen zu "Die Erzlagerstätten von Dobschau und ihre Beziehungen zu den gleichartigen 
Vorkommen der Ostalpen". Z prakt Geol Lagerstättenkunde (Berlin) 16: 506-508

Cambel B, Bagdasarjan GP, Veselský J, Gukasjan RC (1980) To problems of interpretation of nuclear-geochronological data on the age of crystalline rocks of the West Carpathians. Geol Carpath 31: 27-48

CAMbel B, Král J, Burchart J (1990) Isotopic geochronology of crystalline complexes of the Western Carpathians. Veda. pp 1-183 p (in Slovak)

Chovan M, Háber M, Jeleñ S, RoJkovič I (eds) (1994) Ore textures in the Western Carpathians. Slovak Academic Press, pp 1-219

Dallmeyer RD, Neubauer F, Handler R, Fritz H, MüLLER W, PANA D, Putiš M (1996) Tectonothermal evolution of the internal Alps and Carpathians. Evidence from ${ }^{40} \mathrm{Ar} /{ }^{39} \mathrm{Ar}$ mineral and whole-rock data. Eclogae geol Helv 89: 203-227

Dallmeyer RD, Neubauer F, Fritz H (2008) The Meliata suture in the Carpathians: Regional significance and implications for the evolution of high-pressure wedges within collisional orogens. In: SIEGESMUND S, FÜGENSCHUH B, Froitzheim N (eds): Tectonic aspects of the Alpine-Dinaride-Carpathian System. Geological Society of London, Special Publications 298: 101-115

FARYAD SW (1995) Phase petrology and P-T conditions of mafic blueschists from the Meliata unit, Western Carpathians, Slovakia. J Metamorph Geol 13: 701-714

FARYAD SW (1997) Metamorphic petrology of the Early Paleozoic low-grade rocks in the Gemericum. In: GRECULA P, Hovorka D, Putiš M (eds): Geological Evolution of the Western Carpathians. Miner Slov Corp, Geocomplex, Bratislava, pp 309-314

FARYAD SW, DiANIŠKa I (1999) Alpine overprint in the Early Paleozoic of the Gemericum. Miner Slov 31: 485-490 (in Slovak)

Faryad SW, Henjes-Kunst F (1997) K-Ar and Ar-Ar age constraints of the Meliata blueschist facies rocks, the Western Carpathians (Slovakia). Tectonophysics 280: 141-156

Gerdes A, ZeH A (2009) Zircon formation versus zircon alteration-New insights from combined $\mathrm{U}-\mathrm{Pb}$ and $\mathrm{Lu}-\mathrm{Hf}$ in-situ LA-ICP-MS analyses of Archean zircons from the Limpopo Belt. Chem Geol 261: 230-243

Grecula P, Abonyi A, Abonyiová M, Antaš J, BartalSKÝ B, BARTALSKÝ J, DianišKa I, DRnZíK E, ĎuĎA R, Gargulák M, GAZDAČKo L', HudÁČEK J, KOBULSKÝ J, LÖRINCZ L, MACKo J, NÁvESŇ́́́ D, NÉMETH Z, NOVOTNÝ L, RADVANEC M, RoJKovič I, RozLoŽNíK L, RozLOŽNíK O, VARČEK C, Zlocha J (1995) Mineral deposits of the Slovak Ore Mountains. Geocomplex, Bratislava, pp 1-829

HaLAhyjová-Andrusovové G (1959) Mineralogické a paragenetické štúdium ložísk v okolí Dobšinej. MS VVÚGG, PFUK. (in Slovak)

Halahyjová-Andrusovoví G (1961) Mineralogical and paragenetic study of ore deposits around Dobšiná.
Unpublished report, Comenius University, Bratislava, 1-334 (in Slovak)

HaLAhYJová-Andrusovoví G (1964) About the genesis of the Dobšiná ore veins. Geologické Práce, Zprávy 33: 53-69 (in Slovak)

Hovorka D, SpIŠIAK J (1981) Coexisting garnets and amphiboles in metabasites of Rudnany area (the Paleozoic, the Spišsko-gemerské rudohorie Mts., the Western Carpathians). Miner Slov 13, 6: 509-525

HroUdA F, FARYAD SW (2017) Magnetic fabric overprints in multi-deformed polymetamorphic rocks of the Gemeric Unit (Western Carpathians) and its tectonic implications. Tectonophysics 717: 83-98

Hurai V, Harčová E, Huraiová M, Ozdín D, Prochaska W, Wiegerová V (2002) Origin of siderite veins in the Western Carpathians I. P-T-X- $\delta{ }^{13} \mathrm{C}-\delta^{18} \mathrm{O}$ relations in ore-forming brines of the Rudňany deposits. Ore Geol Rev 21: 67-101

Hurai V, Urban M, Konečný P, Thomas R, Lexa O, Schulmann K, Chovan M (2006) Creataceous age of quartz-stibnite veins near Čučma (Spišsko-gemerské rudohorie Mts.). Miner Slov 38: 131-140 (in Slovak)

Hurai V, Prochaska W, Lexa O, Schulmann K, Thomas R, Ivan P (2008) High-density nitrogen inclusions in barite from a giant siderite vein: implications for Alpine evolution of the Variscan basement of Western Carpathians, Slovakia. J Metamorph Geol 26: 487-498

Hurai V, Paquette JL, Lexa O, KoneČný P, DianišKa I (2015) U-Pb-Th geochronology of monazite and zircon in albitite metasomatites of the Rožňava-Nadabula ore field (Western Carpathians, Slovakia): implications for the origin of hydrothermal polymetallic siderite veins. Mineral Petrol 109.5: 519-530

HYNIE O (1922) O príslušnosti a stáří rudní formace v okolí Starých Hor a Španej Doliny. Sbor Klubu př́rodověd (Praha), 21-26 (in Czech)

ILAVSKÝ J (1986) Mineral deposits of the Czechoslovak Carpathians. In: Dunning FW, Evans AM (eds) Mineral deposits of Europe, Vol. 3: Central Europe. Inst Mining Metall and Min Soc London, pp 146-173.

Ivan P (1982) Position and significance of fuchsite in evolution of mineralization of the Spišsko-gemerské Rudohorie (West Carpathian Mts). Acta geol eogr Univ Comen, 38: 157-173

JeŘábek P, Lexa O, Schulmann K, PlašínKa D (2012) Inverse ductile thinning via lower crustal flow and foldinduced doming in the West Carpathian Eo-Alpine collisional wedge. Tectonics 31.5

Kantor J, Rybár M (1979) Radiometric ages and polyphase character of Gemeride granites. Geol Carpath 30: 433-447

KetTNER R (1921) Příspěvek k poznání geologie Spišskogemerského rudohoří mezi Gelnicí a Dobšinou. Sbor Stát geol Úst, Odd geol 1: 21-28 (in Czech) 
Kiefer S, Majzlan J, Chovan M, Števko M (2017) Mineral compositions and phase relations of the complex sulfarsenides and arsenides from Dobšiná (Western Carpathians, Slovakia). Ore Geol Rev 89: 894-908

KodĚra, M, Andrusovová, G, Belešová, O, Briatková, D, Dávidová, Š, Fejdiová, V, Hurai, V, Chovan, M, Nelišerová, E, Zeniš, P (1990) Topographic Mineralogy of Slovakia-Part 2. Veda, Bratislava, pp 585-1098 (in Slovak)

Kovách A, Svingor E, Grecula P (1986) Rb-Sr isotopic ages of granitoide rocks from the Spiško-gemerské rudohorie Mts., Western Carpathians, Eastern Slovakia. Miner Slov 18: 1-14

Kozur H, Mock R (1973) Zum Alter und zur tektonischen Stellung der Meliata-Serie des Slowakischen Karstes. Geol Zbor Geologica carpath 24: 365-374

Králiková S, Vojtko R, Hók J, FüGenschuH B, Kováč M (2016) Low-temperature constraints on the Alpine thermal evolution of the Western Carpathian basement rock complexes. J Struct Geol 91: 144-160

Lee JY, Marti K, Severinghaus JP, Kawamura K, Yoo HS, LEE JB, KIM JS (2006) A redetermination of the isotopic abundances of atmospheric Ar. Geochim Cosmochim Acta 70: 4507-4512

LeXa O, Schulmann K, JežeK J (2003) Cretaceous collision and indentation in the West Carpathians: View based on structural analysis and numerical modeling. Tectonics 22.6

Majzlan J, Chovan M, Kiefer S, Gerdes A, Kohút M, Siman P, KonečnÝ P, ŠteVko M, Finger F, WaitZINGER M, BiroŇ A, Luptáková J, ACKerman L, Hora JM (2020) Geochronology and timing of hydrothermal mineralizations in the Nízke Tatry Mts and adjacent areas (Western Carpathians). Geol Carpath 71(2): 113-133

Maluski H, Rajlich P, Matte P (1993) 40Ar-39Ar dating of the Inner Carpathians Variscan basement and Alpine mylonitic overprinting. Tectonophysics 223: 313-337

Markey R, Stein HJ, Hannah JL, Zimmerman A, Selby D, CREASER RA (2007) Standardizing Re-Os geochronology: a new molybdenite reference material (Henderson, USA) and the stoichiometry of Os salts. Chem Geol 244(1-2): 74-87

Marrett RA, AlLmendinger RW (1990) Kinematic analysis of fault-slip data. J Struct Geol 12: 973-986

MáŠKA M (1957) Poznámky k předtercierní metalogenesi Západních Karpat, zvláště Spišsko-gemerského Rudohoří. Geol Práce, Zoš (Bratislava) 46: 96-106 (in Czech)

MeSARČÍK I, KILÍK J, LÖRINCZ L, ČAPO J, BAJTOŠ P, LEHOCZKÝ M, Gluch A, Mesarčíková M (2001) Komplexné zhodnotenie zatvoreného ložiska Dobšiná. ŠGÚDŠ Bratislava, pp 1-223 (in Czech)

Morelli RM, Creaser RA, Selby D, Kontak DJ, Horne RJ (2005) Rhenium-Osmium arsenopyrite geochronol- ogy of Meguma Group gold deposits, Meguma Terrane, Nova Scotia, Canada: evidence for multiple gold mineralizing events. Econ Geol 100: 1229-1242

Morelli RM, Bell CC, Creaser RA, Simonetti A (2010) Constraints on the genesis of gold mineralization at the Homestake Gold Deposit, Black Hills, South Dakota, from rhenium-osmium sulfide geochronology. Miner Depos 45: 461-480

Novotná N, JeřábeK P, Pitra P, LeXa O, RACEK M (2015) Repeated slip along a major decoupling horizon between crustal-scale nappes of the Central Western Carpathians documented in the Ochtiná tectonic mélange. Tectonophysics 646: 50-64

ODIN GS (1982) How to measure glaucony ages? In: Odin GS (ed) Numerical Dating in Stratigraphy,, Wiley, pp $387-403$

OzDín D (2003) Mineralogy and genesis of the siderite mineralization of the Dumbier Tatry Mts. PhD Thesis, Comenius University, Bratislava, pp 1-197 (in Slovak)

OzDín D (2008) Mineralogy and genetical study of hydrothermal siderite-quartz-sulphidic veins in Jedl'ové Kostol'any, the Tríbeč Mts. Mineralogia Special papers 32(1): pp 1-123

OzDín D (2010) Mineralogical and genetical study of primary hydrothermal siderite-quartz-sulphidic veins hosted by Tatric and Veporic unit (Western Carpathians, Slovakia) Acta mineral petrogr Abstract Ser 6, 240

Ozdín D (2015) Mineralogická charakteristika Fe-zrudnenia východne od L’ubietovej. Esemestník 4, 2, 37-38 (in Slovak)

OzDín D, SeJKora J, RAčKo M (2016) Datovanie a paragenetická charakteristika hydrotermálnej mineralizácie v okolí L'ubietovej. In: Nerastné suroviny v 21. Storočí. SNM Bratislava, 42-43 (in Slovak)

PAPP K (1919) Die Eisenerz und Kohlenvorräte des Ungarischen Reiches. Ung geol Reichsanst, Budapest, pp 1-638 (in German)

PlašínKa D, Broska I, Kissová D, DunkL I (2007) Zircon fission-track dating of granites from the Vepor-Gemer Belt (Western Carpathians): constraints for the Early Alpine exhumation history. J Geosci 52: 113-123

ProchaskA W (2016) Genetic concepts on the formation of the Austrian magnesite and siderite mineralizations in the Eastern Alps of Austria. Geol Croat 69: 31-38

Putiš M, DANišÍK M, RužIČKA P, SCHMIEdT I (2014) Constraining exhumation pathway in an accretionary wedge by (U-Th)/He thermochronology - Case study on Meliatic nappes in the Western Carpathians. J Geodyn 81: 80-90

RADVANEC M (1994a) Petrology of the gneiss-amphibolite complex at the northern part of the Rudnany ore field: Part I. P-T $-\mathrm{x}$ conditions and metamorphic zones. Miner Slov 26: 223-238 (in Slovak)

Radvanec M (1994b) Petrology of the gneiss-amphibolite complex at the northern part of the Rudňany ore field: 
Part II. Sequence of crystallization of minerals in granite after local melting of metasemipelite in the biotite zone of regional metamorphism (P-3.5 kbar). Miner Slov 26: 239-250 (in Slovak).

Radvanec M, Grecula P (2016) Geotectonic and metallogenetic evolution of Gemericum (inner Western Carpathians) from Ordovician to Jurassic. Miner Slov 48: 105-118

Radvanec M, Grecula P, ŽÁK K (2004) Siderite mineralization of the Gemericum superunit (Western Carpathians, Slovakia): Review and a revised genetic model. Ore Geol Rev 24: 267-298

Roberts NMW, Rasbury ET, Parrish RR, Smith CJ, Horstwood MSA, CONDON DJ (2017) A calcite reference material for LA-ICP-MS U-Pb geochronology. Geochem Geophys Geosyst 18.7: 2807-2814

RoJKOVIČ I (1977) Mineralogical and geochemical study on opaque minerals of the Rudňany deposit. Open File Report, ŠGÚDŠ-Geofond, Bratislava, pp 1-232 (in Slovak)

ROJKOVIČ I, KONEČNÝ P (2005) Th-U-Pb dating of monazite from the Cretaceous uranium vein mineralization in the Permian rocks of the Western Carpathians. Geol Carpath 56: 493-502

RoJkovič I, Novotny L, Háber M (1993) Stratiform and vein $\mathrm{U}, \mathrm{Mo}$ and $\mathrm{Cu}$ mineralization in the Novoveská Huta area, CSFR. Miner Depos 28: 58-65

RozLožNíK L (1959) Tektonické postavenie rudných ložísk v okolí Dobšinej. Acta geol geogr Univ Comen, Geol č. 2: $167-175$

RozLOžNí L (1965) Analýza štruktúrno-metalogenetických elementov medzi Dobšinou a Mlynkami. Sbor Geol Vied Západ Karpaty 4: 29-93

RozložNík, L (1989) Problémy veku a zdroja sideritovej formácie Západných Karpát. Geol Průz 31: 67-72 (in Slovak)

Selby D, Creaser RA (2004) Macroscale NTIMS and microscale LA-MC-ICP-MS Re-Os isotopic analysis of molybdenite: Testing spatial restrictions for reliable Re-Os age determinations, and implications for the decoupling of Re and Os within molybdenite. Geochim Cosmochim Acta, 68: 3897-3908

Smoliar MI, Walker RJ, Morgan JW (1996) Re-Os ages of group IIA, IIIA, IVA, and IVB iron meteorites. Science 271(5252): 1099-110

SPeAR FS, PARrish RR (1996) Petrology and cooling rates of the Valhalla Complex, British Columbia. J Petrol 37: 733-765

SPIŠIAK J, Hovorka D, Ivan P (1985) Klátovská skupina - reprezentant metamorfitov amfibolitovej fácie paleozoika vnútorných Západných Karpát. Geol Práce, Spr: 82, 205-220 (in Slovak)
Tartèse R, Ruffet G, Poujol M, Boulvais P, Ireland TR (2011) Simultaneous resetting of the muscovite K-Ar and monazite $\mathrm{U}-\mathrm{Pb}$ geochronometers: a story of fluids. Terra Nova, 23:390-398

ULRICH F (1928) Výskyt rutilu na sideritových žilách u Rožňavy na Slovensku a jeho postavení v žilné paragenesi. Rozpr Čes Akad Věd Umění (Praha), Tř. II, 37, č. 8, pp 1-19 (in Czech)

Urban M, Thomas R, Hurai V, KoneČný P, Chovan M (2006) Superdense $\mathrm{CO}_{2}$ inclusions in Cretaceous quartzstibnite veins hosted in low grade Variscan basement of the Western Carpathians, Slovakia. Miner Depos 40: 867-873

VARČEK C (1962) Vývoj hydrotermálnej mineralizácie Spišsko-Gemerského rudohoria v čase a priestore. Geol Práce, Zoš 61: 101-112 (in Slovak)

VARČEK C (1985) Metalogenetic characteristics of the Spišsko-gemerské rudohorie Mountains and the position of the Rudňany ore field. In: Cambel B, Jarkovský J (eds) The Rudňany Ore Field-Geochemical and Metallogenetic Characteristics. Veda, Bratislava, pp 61-77 (in Slovak)

VILLA IM (2015) 39Ar-40Ar geochronology of mono- and polymetamorphic basement rocks. Periodi Mineral 84, 3B (Special Issue), 615-632

Vojtko R, Králiková S, JeŘÁbek P, Schuster R, DanišíK M, FügenschuH B, Minár J, Madarás J (2016) Geochronological evidence for the Alpine tectono-thermal evolution of the Veporic Unit (Western Carpathians, Slovakia). Tectonophysics 666: 48-65

VozÁrová A, Laurinc D, Šarinová K, Larionov A, Presnyakov S, Rodionov N, Paderin I (2013) Pb ages of detrital zircons in relation to geodynamic evolution: Paleozoic of the northern Gemericum (Western Carpathians, Slovakia). J Sediment Res 83: 915-927

VozÁroví A, KoneČNÝ P, Šarinová K, VozÁr J (2014) Ordovician and Cretaceous tectonothermal history of the Southern Gemericum Unit from microprobe monazite geochronology (Western Carpathians, Slovakia). Int J Earth Sci (Geol Rundsch) 103: 1005-1022

Wise SA, Watters RL (2011) Reference Material 8599 Henderson Molybdenite. National Institute of Standards and Technology, Report of Investigation, $3 \mathrm{p}$

WOLDŘICH J (1912) Montanisticko-geologické studie ve Spiško-gemerském rudohoří, severně od Dobšiné v Uhrách. Rozpr Čes Akad Věd, Ř mat přír Věd (Praha) 21: 1-23 (in Czech)

WOLDŘICH J (1927) K stratigrafii paleozoika Slovenského Rudohoří v Karpatech. Práce Morav př́rodověd Společ (Brno), 4, č. 1, ss. 1-16 (in Czech)

ZouBeK V (1937) Dva nálezy rud v mezozoiku d’umbierské zóny. Věst Stát geol Úst 13, č. 4-;5, ss. 211-224 (in Czech) 